\title{
Institutions and Organizational Structure: The Case of State-Owned Corporate Pyramids
}

\author{
Joseph P. H. Fan* \\ The Chinese University of Hong Kong \\ T. J. Wong \\ The Chinese University of Hong Kong \\ Tianyu Zhang \\ The Chinese University of Hong Kong
}

\begin{abstract}
Pyramidal organizational structures are common throughout the world. This article considers an explanation for pyramids built by the state: separating firms from political interference. Although intermediate pyramidal layers insulate managers from a pyramid's top owners and hence induce agency costs, they also minimize political costs of state intervention. All else equal, the optimal division of power between the government and the managers should be the point at which the marginal agency costs are equal to the marginal political costs. Our empirical results, based on hand-collected data for 742 local government-owned Chinese business groups are generally in line with this hypothesis. (JEL: D21, D23, G32, L22, L32, P31).
\end{abstract}

\section{Introduction}

In a pyramid-like organizational structure, the controlling owner at the top of the pyramid controls a firm indirectly through layers of intermediate companies. Such structures are common throughout the world and have been the subject of a growing body of research (La Porta et al. 1999; Claessens et al. 2000; Khanna and Yafeh 2007). To date, however,

An earlier version of this article is entitled "The Emergence of Corporate Pyramids in China." We thank Chong-En Bai, Utpal Bhattacharya, Robert Bushman, Wai Sum Chan, Peter Högfeldt, Inchi Hu, Christian Leuz, Qiao Liu, Ron Masulis, Paul Malatesta, Randall Morck, Harold Mulherin, Joseph Piotroski, Jordan Siegel, Garry Twite, Daniel Wolfenzon, Bernard Yeung, and Hua Zhang, workshop participants at University of Chicago, the Chinese University of Hong Kong, City University of Hong Kong, Harvard Business School, and Tsinghua University, and participants at the 2005 International Corporate Governance Conference in Asia and China in Shanghai and the Conference on Corporate Governance of Closely Held Firms at Copenhagen Business School for valuable comments. We thank the Corporate Governance Center of Nankai University for Survey Assistance. The usual disclaimer applies.

* CUHK Business School and Institute of Economics and Finance, The Chinese University of Hong Kong, Hong Kong. Email: pjfan@cuhk.edu.hk

The Journal of Law, Economics, and Organization, Vol. 29, No. 6 doi:10.1093/jleo/ews028

Advance Access published on September 13, 2012

(C) The Author 2012. Published by Oxford University Press on behalf of Yale University.

All rights reserved. For Permissions, please email: journals.permissions@oup.com 
this literature focuses on privately controlled pyramids. As a result, we know little about corporate pyramids formed by the state. Understanding government-controlled pyramids is important as they are popular in a number of countries: including transitional economies, such as China, Hungary (Voska 1993), Russia (Chernykh 2008), and the Czech and Slovak Republics (OECD 2005), as well as in developed economies such as Austria (OECD 2005) and France (de Jong et al. 2010). This article attempts to fill this gap in the literature by proposing an explanation for pyramids built by the state: separating firms from political interference.

To test this explanation, we focus on the case of China. The Chinese setting has several important advantages for our purposes. First, in China, state assets and their controlling ownership are not freely transferable across firm boundaries. As a result, state owners almost always possess $100 \%$ of the equity ownership of a pyramid's firms, which precludes equity financing from serving as the primary reason for a pyramidal structure. This is consistent with Khanna and Rivkin (2001), who find no evidence that capital market imperfections alone explain the prevalence of business groups in emerging markets. Further, because state owners are unable to use outright sales as a means to transfer decision rights in a firm to a third party, as is typical in a market economy (Burkart et al. 1997; Baker et al. 1999), a transfer of decision rights that increases autonomy can be achieved only via a mechanism — such as a pyramid - which is short of an actual transfer of ownership. Second, China's market economy is young. This allows us to investigate corporate pyramids near their inception, during a time when decentralization has been a chief part of the country's market reforms (Grove et al. 1994; Brandt and Zhu 2000; Maskin et al. 2000). Third, China's markets and geographic regions provide sufficient variation in institutional settings to facilitate measurement of controlling owners' (i.e., local governments') incentives to decentralize decision-making power to firm managers through pyramidal organizational structures.

In reviews of China's economic reform experience, Qian (1996) and Qian and $\mathrm{Wu}$ (2003) argue that reform of state-owned enterprises (SOEs) has been associated with a reduction in the political costs of government interference in the operations of the firms. Political costs, such as excessive taxation or other policy burdens on the SOEs (Lin and Li 2008), are considered a form of organizational cost of a firm under government ownership that could lower operating efficiency and profitability (Shleifer and Vishny 1994, 1998). Building on this argument, we investigate whether local governments use pyramids to reduce SOE political costs stemming from the government's interference. More specifically, we conjecture that organizational pyramids give governments more credibility in committing to nonintervention than simply a policy prescription that calls for increased delegation of decision rights to managers of SOEs. This is because the complex organizational structure of pyramids 
increases the government's cost of obtaining sufficiently timely information to interfere in the day-to-day operations of the firm (Aghion and Tirole 1997), and thus prevents an intervening government from imitating a pyramidal strategy. Based on this conjecture, we hypothesize that the extensiveness of SOE pyramids is positively associated with local governments' incentives to reduce their interference and hence the resulting political costs to the firms.

Our empirical evidence is consistent with this hypothesis. In particular, using a comprehensive sample of 742 initial public offering (IPO) firms, majority owned by local governments in China, we find that local governments form more extensive pyramids when they have incentives to lower firm political costs arising from interference. The government's weaker incentives to intervene induce it to credibly transfer decision rights to management through pyramids.

While the reduction of SOE political costs leads to more decentralization of power through pyramid formation, adding more layers could increase agency costs, as the higher information costs make monitoring more difficult. Our empirical results show that more extensive pyramidal structures are associated with stronger legal or market discipline on firm managers, indicating that stronger institutions reduce agency problems arising from empowering management.

Further supporting our conjecture that pyramids insulate firms from government intervention, we find a significant positive association between the number of pyramidal layers and the extent of firm managerial professionalism, employment efficiency, total factor productivity, and profitability. In additional analyses, we survey government officials in charge of state asset management and find evidence that managers of the firms who are part of pyramid structures have more decision rights than managers of the firms who are directly linked to the governments.

The above results on the performance effects of state-owned pyramids differ from those in prior studies based on private ownership, which typically find negative performance effects (Claessens et al. 2002; La Porta et al. 2002; Lemmon and Lins 2003). Moreover, the findings that organizational pyramid are more extensive in regions with stronger institutions contrasts with prior findings that pyramids prevail in weak institutional environments. As we discuss below in more detail, the political cost factor helps explain why state-owned firms' organizational responses to the institutional environment differ from those of the private firms.

Our study enlarges the body of knowledge about organizational pyramids. Earlier papers argue that pyramidal structures allow a controlling owner to consume private benefits, for instance, by expropriating wealth from minority shareholders (Bebchuk 1999; Wolfenzon 1999; Bebchuk et al. 2000; Bertrand et al. 2002; Morck et al. 2004). This negative aspect of organizational pyramids, however, is not the only view prevailing in the literature. In a study of the history of British trading business groups in the late 19th and early 20th centuries, Jones (2000: 185) points 
out that given the widespread contractual relationships between controlling owners and affiliated firms, it is surprising how few legal cases occurred. "It would seem that the trading companies seldom sought to pursue their interests to such an extent that outside shareholders were blatantly dis-advantaged." More recent studies find countervailing advantages of business groups and their pyramidal structures. Khanna and Thomas (2009) find evidence of information-sharing advantages among business group members affiliated through interlocking directors. Other studies find that pyramidal structures relieve affiliated firms' financial constraints (Almeida and Wolfenzon 2006; Almeida et al. 2011) and facilitate investment (Masulis et al. 2011). The literature also shows that tax policies can influence organizational structures (Morck 2005; Morck and Yeung 2005). We add to this emerging literature by identifying an additional rationale for pyramidal organizational structures.

The remainder of this article proceeds as follows. Section 2 discusses the relevant literature and develops our hypotheses on the emergence of corporate pyramids in China. Section 3 reports empirical results on the determinants of corporate pyramids. Section 4 reports the evidence on the associations between corporate pyramids and firm performance measures. Section 5 presents survey results. Finally, Section 6 presents our conclusions.

\section{Literature Review and Hypothesis Development}

In this section, we discuss the literature on allocation of decision rights within organizations, and on the emergence and organization of China's modern enterprises. We then discuss key institutional factors that influence local government incentives for organizing their enterprises into pyramids, and the association between pyramids and firm efficiency.

\subsection{Division of Power within an Organization}

The literature examines the importance of organizational design in the allocation of firm decision rights. Williamson (1985) posits that in a multisegment firm, headquarters specializes in allocating human and financial capital among its various divisions while giving divisional managers decision rights with respect to local activities. This view finds support in Jensen and Meckling (1992), who show that such delegation can enhance efficiency as it co-locates local knowledge (which cannot be transferred without cost) and decision rights, and provides local managers high-power incentives. Stein (2002) further shows that when the transmission of information from divisional managers to headquarters is costly, a firm is more likely to adopt a decentralized decision structure than a hierarchical structure.

A question that naturally arises is how can firm headquarters credibly commit to decentralization? Simply instructing divisional managers to make decisions is not sufficient, as ex post reneging/intervention is 
easy for headquarters managers whereas costly to divisional managers. Prior work suggests that the cost of transmitting information is a key factor affecting the credibility of a decentralization program. For instance, Cremer (1995) shows that, in the context of arm's-length relationships, lower information costs decrease the principal's (i.e., headquarters') incentive to commit not to intervene. This weakens the agent's (i.e., divisional manager's) incentive to make decisions and thus leads to counterproductive activities. In a model in which delegating authority increases agent initiative, Aghion and Tirole (1997) shows that an empowered manager may act with self-interest at the expense of the principal. Whether the principal will delegate authority, therefore, depends on how informed the principal is about the agent's proposal and the cost of collecting information: if the principal is informed, he will retain the authority, whereas if the principal is uninformed he will delegate real authority to the agent while retaining formal authority. Prat (2005) further distinguishes two types of information that a principal can have about the agent, namely, information about the consequences of the agent's action and information about the action itself. Prat shows that the principal's knowledge about an action's consequences (such as performance outcomes) facilitates delegation, whereas transparency about actions (such as day-to-day decisions) can impede delegation-if the principal can observe the agents' activities, the agent will have an incentive to behave in a conformist manner.

Taken together, the above studies suggest the importance of information barriers between a firm's headquarters and divisions to enforce decentralized decision making within an organization. Notwithstanding theoretical development on this subject, however, few empirical tests of this theory exist. Two notable exceptions are Baker (1992) and Rajan and Wulf (2006), which both find that, over time, large US conglomerates have adopted more decentralized structures, with headquarters giving divisional managers more decision rights.

\subsection{Division of Power within a State-owned Organization}

A state-owned firm faces organizational costs associated with two types of internal conflict of interest, namely, political costs associated with government (owner) incentive to intervene in the firm, and agency costs associated with a manager's incentive to expropriate wealth from the firm.

As Qian (1996) points out, a fundamental motivation for empowering SOE managers in the first place is to reduce government interference, and therefore to lower the firm's political costs. Although Chinese-listed SOEs are restructured into joint stock companies with outside shareholders post-IPO, the government remains the majority owner and retains control of the board (Fan et al. 2007) and the right to appoint key officers, such as the chairman and CEO (Qian 1996). Government officials who have control rights over listed SOEs often pursue their own private political objectives at the expense of outside shareholder's 
interest in maximizing firm value. For instance, the government owner can compel the firm to build public infrastructure, pay more taxes, or provide excess employment in the locality to alleviate fiscal and employment problems.

In addition to reducing political costs, empowering SOE managers is likely to induce high-power incentives and improve productivity. The owner of an SOE, a governmental agency, typically faces decisionmaking constraints due to insufficient expertise and information, and thus allocates some decision rights to SOE managers. However, empowered managers can expropriate substantial gains from the SOE, resulting in severe agency costs. This is because, unlike a private firm, an SOE does not have a "true" owner looking after firm interests.

All else equal, the optimal division of power between the government and the SOE manager should be the point at which marginal agency costs are equal to marginal political costs.

\subsection{Decentralization and State-owned Pyramids}

If the government chooses to decentralize firms' decision rights, it can employ a pyramidal organizational structure to credibly decentralize decision making without transferring firm ownership, i.e., delegate real authority without transferring formal authority (Aghion and Tirole 1997). Of course, the government has the power to intervene at any time, particularly through oversight, with respect to personnel decisions. However, compared with a policy mandate not to intervene, a pyramidal organizational structure can help the government commit to nonintervention, because the complex organizational structure of a pyramid makes it costly for the government to obtain sufficiently timely information to intervene in the day-to-day operations of the firm (Prat 2005). Information at the bottom of the pyramid must travel through an intermediate layer(s) before reaching the top, and the managers of intermediate layer(s), constrained by their own inefficiencies and conflicts of interest, may not deliver timely and objective information to top management (or equivalently, may not monitor the bottom layer of the firms on behalf of the government at the top). Thus, ironically, one advantage of an extensive vertical pyramid is that it is highly bureaucratic, making information transmission ineffective - an important condition for decentralization, as emphasized in Cremer (1995), Aghion and Tirole (1997), and Baker et al. (1999).

Thus, a pyramid structure can be adopted as a credible mechanism to reduce government intervention. As Shirley and Walsh (2001) observe, "if an enterprise is run as a department of a ministry,... then political interventions will be easy and common. Alternatively, if the government acts as the dominant shareholder of a largely independent firm, ... political intervention may be possible but is more costly and more transparent." Given the higher information and monitoring costs associated with pyramids, a government is not likely to use the pyramidal structure if it is worried about losing control of the firm. Rather, the government is likely 
to use the more costly pyramidal structure only if it wants to credibly delegate control to firm managers.

\subsection{Formation of State-owned Pyramidal Groups in China}

Before 1990, China's state assets were managed according to a Soviet style central planning system. Since the 1990s, however, China has witnessed a wave of business group formation in which state assets have been separated from governmental agencies, spun off from parent SOEs, and injected into newly established subsidiaries. ${ }^{1}$ The reform and resulting organizational transformation reflect the Chinese government's effort to resolve serious conflicts of interest and low efficiency within SOEs. A general feature of the reform is the transfer of SOE decision rights from the central government to local governments. Although the central government continues to intervene in local government and firm decisions, it has not intervened to the point of overwhelming the general trend toward increased decentralization.

Since the creation of the stock markets in Shanghai and Shenzhen in the early 1990s, local governments have used their newly gained power to spin out productive assets from their SOEs, organizing them into corporations, and then partially privatize some of the firms through IPOs. By 2001, over 1000 companies had gone public in this way, with most of these firms remaining majority owned by local governments.

A local government can choose to organize its ownership and control of a publicly traded company in one of the two ways. First, the local government can hold its shares of the newly listed company directly through a state asset management agency. In this case, the ownership structure of the company is simple: the local government directly owns a controlling stake, whereas minority equity investors collectively own the rest (see Figure 1 for an example). Alternatively, the local government can indirectly own the listed company through a pyramid consisting of one or more intermediate companies. In this case, if there is only one intermediate company, it is usually a parent SOE or a state asset management company, which specializes in managing the state assets, while the state asset management agency at the top of the pyramid continues to serve the government's administrative and regulatory functions (Figure 2). However, if there are multiple intermediate layers, the local government has most likely transferred the control rights of the listed firm to a large SOE group with multiple layers of companies. In either case, these intermediate pyramidal layers are nonpublicly traded SOEs solely owned by the local government

1. This process typically occurs through several rounds of joint ventures established by SOEs and their subsidiaries with other government and SOE partners (Qian 1995; Tenev et al. 2002; Garnaut et al. 2005). A subsidiary may further spin off assets into another newly created subsidiary, and so on. The system of state-owned business groups is called "Multi-layer Legal Person System (多级江人制)” (Wu 2005). Keister (2000) provides an excellent description of the business groups in China and their role in the country's economic development. 


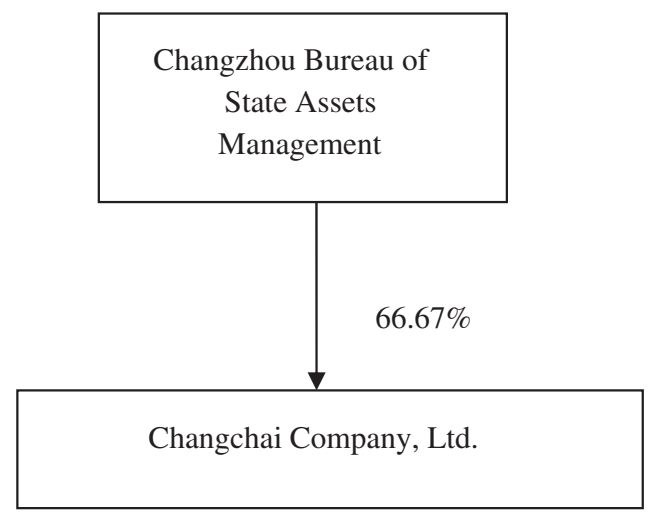

Figure 1. A Listed Company Directly Controlled by a Local Government. Source: The 2001 annual report of Changchai Company, Ltd.

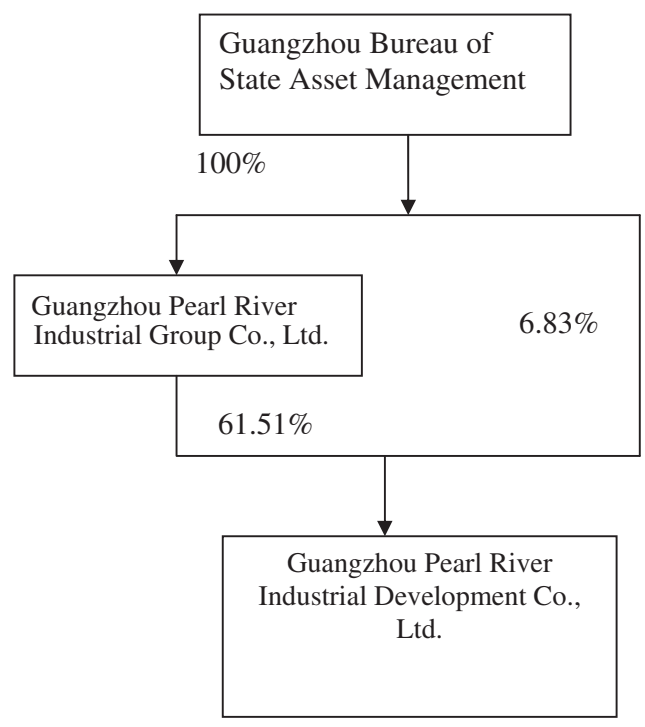

Figure 2. A Listed Company Controlled by a Local Government through a Two-layer Pyramid. Source: The 2001 annual report of Guangzhou Pearl River Industrial Development Co., Ltd.

or jointly owned by the local government and other government agencies; nongovernment equity participation in the intermediate SOEs is uncommon, due to state regulations prohibiting free dilution of state ownership. The chain of intermediate companies is typically formed over a period prior to the IPO through a series of SOE asset restructurings. To illustrate the reform and the business group formation process, Appendix A.1. summarizes the city of Shanghai's state asset management system reform and the associated creation of the Shanghai Construction Group. 


\subsection{Determinants of Pyramids}

Based on the discussion above, a local government can decide to have a state asset management agency that directly control the listed firm or it can delegate its control to a state asset management company or SOE group. By choosing the latter option, the additional intermediate layers make it more difficult for the government to intervene in the firm's decisionmaking process.

To the extent that the above argument holds, we can test for the different roles of political costs and agency costs in state pyramid formation. First, we predict that governments' incentives to interfere in an SOE, which induce high political costs on the firm, will lead to less extensive pyramid formation. For example, when the government suffers from poor fiscal conditions or high unemployment, it has incentives to influence the firms' operations so as to alleviate these problems in the local region. In such a situation, the local government is less willing to reduce the firm's political costs by relinquishing control through building pyramids. However, the government will have incentives to lower the firm's political costs and to relinquish its control through pyramids when the region suffers less from fiscal deficits and unemployment.

Second, we predict that agency costs have an effect on the extensiveness of SOE pyramids. The reason for this is that when agency costs are low, it is in the government's best interest to delegate its decision rights in the firms to their management. By transferring decision rights to managers who possess professional expertise and local knowledge, decentralization can enhance firm decision-making efficiency (Jensen and Meckling 1992), which is particularly important in a competitive market environment. However, the government will decentralize less by building fewer pyramidal layers when agency costs are high. In regions with strong market discipline and legal enforcement, agency costs are likely to be low because the interests of managers are aligned with those of the firms' owners. Thus, we expect to find more extensive pyramid formation for firms operating in regions with stronger market discipline and legal enforcement.

The above discussion suggests that the degree of decentralization depends on both political costs, affected by the local government's incentives to intervene in firm decisions, and agency costs, affected by the market and legal institutional factors. The complexity of corporate pyramidal layers linked to a publicly traded company, a proxy for effective delegation of decision rights, should therefore vary systematically with these government incentives and institutional factors. Accordingly, we have the following two hypotheses:

H1: The weaker the local government's incentive to intervene in firm decisions, the more extensive is the firm's pyramidal structure. 
H2: The stronger the market and legal institutions under which the firm operates, the more extensive is the firm's pyramidal structure.

If the need to protect against political intervention is small, as is the case when local governments are not under fiscal or social pressure, then why not design the pyramidal structure to minimize agency costs, that is, why not have a smaller pyramid? A nonintervening government that directly owns a firm could inform the firm's manager that such manager is free to make decisions. But this is the same strategy as that of an intervening government. The manager will therefore attempt to verify the government's type with regard to the intervention. However, to the extent that the manager cannot fully verify the government's type, the manager will face uncertainty about the risk of ex post holding up by the government and hence will hesitate to buy in ex ante. Thus, to credibly commit to decentralize the firm's decision rights, the nonintervening government will use an alternative, costly method (i.e., a pyramid) to differentiate itself from an intervening government.

\subsection{Pyramids and Efficiency}

If pyramidal layers serve as a device to separate firms from political interference, we should see that firms under more complex pyramidal structures are associated with greater managerial professionalism and higher operating efficiency relative to firms under less complex structures. This leads to the following hypothesis:

H3: The number of layers in a firm's pyramidal structure is positively associated with post-IPO managerial professionalism and operating efficiency.

However, given the degree to which delegation and the complexity of pyramidal structures are determined by the political and economic institutions of the regions in which a firm operates, whether the number of pyramid layers is associated with performance and operating efficiency after taking these institutional effects into account is an open question. We attempt to control for such effects in our empirical analysis in the next section.

\section{Empirical Results-Determinants of Corporate Pyramids}

\subsection{Sample}

Our sample consists of 742 local SOEs at their IPO year. By focusing on the IPO year, we are able to examine the causes and effects of pyramids near their inception. Since 2001, publicly traded companies in China have been required to disclose detailed ownership information about their controlling shareholders, including the structures of pyramidal chains, in annual reports. However, we wish to identify the ownership and organizational structures of these companies around their IPO, when these 
structures were initially determined. We therefore trace the ownership and organizational structures of each company traded on the Shanghai or Shenzhen Stock Exchanges back to the IPO year using the information disclosed in their 2001 annual reports and other supplementary sources, including company prospectuses and media reports. ${ }^{2}$ If there is no change in controlling ownership between a company's IPO year and 2001, we consider the ownership structure to have remained the same since the IPO unless supplementary information indicates a change in ownership structure. ${ }^{3}$ If there is a change in controlling ownership, we identify the controlling shareholder and the ownership structure of the IPO year from the IPO prospectus, media reports, and the websites of the company and its affiliated companies. Most listed SOEs are restructured and spun off from parent SOEs prior to their IPOs. The restructuring processes are disclosed in IPO prospectuses, which also provide information about the identities of ultimate shareholders.

To test for the effects of regional political and economic institutions on ultimate owners' decisions to form pyramids, and hence on the decentralization of the firm decisions, we focus on firms controlled by provincial or county governments. Thus, starting with the complete list of 1140 IPO firms in China during the period 1993 through 2001, we exclude firms controlled by the central government (14\% of the population), private owners $(5 \%)$, collectives $(4 \%)$, other owner types (including the military, public universities, public research institutes, financial intermediaries, and unions) (5\%), and firms whose ultimate owners cannot be identified (3\%). We also exclude firms whose ownership or financial data are unavailable $(4 \%)$. Our final sample, as described in Table 1, consists of 742 unique local government-controlled firms ("local SOEs" hereafter) representing $65 \%$ of all IPO firms in China during the period 1993 through 2001. As is evident from Table 1, the year-by-year sample of local SOEs covers the majority of IPOs in almost all of the years we consider.

\subsection{Measuring the Extent of Corporate Pyramids}

For a given company, we identify all intermediate ownership chains connecting the company and its ultimate controlling owner. We measure the extent of the pyramidal structure between the company and its controlling owner as the number of intermediate layers of the longest pyramidal chain (in the case of multiple chains).

To illustrate how we identify and measure the extent of Chinese-listed firms' pyramidal structures, first consider Changchai Company, which

2. Survivorship bias is unlikely a concern because no firm is de-listed prior to 2001 .

3. It is possible that, subsequent to IPO, a controlling owner reorganized the company's ownership/organizational structure without changing controlling owner status. Using 2001 data to construct the IPO-year pyramidal structure would introduce measurement bias. In an untabulated robustness check, we rerun key regressions in this article using observations solely from 2001 and find similar results. 
Table 1. Sample

\begin{tabular}{|c|c|c|c|c|c|c|}
\hline \multirow[t]{2}{*}{ Listing year } & \multicolumn{4}{|c|}{ Number of pyramidal layers } & \multirow[t]{2}{*}{ Total } & \multirow{2}{*}{$\begin{array}{l}\text { As a percentage of } \\
\text { total IPO firms (\%) }\end{array}$} \\
\hline & 1 & 2 & 3 & 4 or more & & \\
\hline Before 1993 & 16 & 13 & 6 & 1 & 36 & 67.92 \\
\hline 1993 & 54 & 34 & 5 & 0 & 93 & 75.00 \\
\hline 1994 & 42 & 32 & 5 & 0 & 79 & 71.17 \\
\hline 1995 & 7 & 8 & 2 & 0 & 17 & 70.83 \\
\hline 1996 & 33 & 82 & 18 & 0 & 133 & 65.84 \\
\hline 1997 & 24 & 94 & 14 & 2 & 134 & 65.05 \\
\hline 1998 & 8 & 59 & 7 & 0 & 74 & 69.81 \\
\hline 1999 & 6 & 43 & 10 & 2 & 61 & 62.24 \\
\hline 2000 & 7 & 50 & 6 & 2 & 65 & 47.45 \\
\hline 2001 & 3 & 37 & 9 & 1 & 50 & 63.29 \\
\hline Total & 200 & 452 & 82 & 8 & 742 & 65.09 \\
\hline
\end{tabular}

This table reports distribution of pyramidal layers of sample firms by IPO year. The sample is composed of 742 newly listed local government-controlled firms, representing around 65\% of all IPO firms in China between 1993 and 2001. The number of pyramidal layers is defined to be one when a government agency directly controls the listed firm, two when there is one intermediate company between the government agency and the listed firm, and so on. The number of pyramidal layers is counted from the longest controlling chain in case of multiple chains.

went public in 1994. Although publicly listed companies were not required to disclose their detailed organizational/ownership structures until 2001, Changchai Company reported its ownership structure in the 1994 annual report, showing that $66.67 \%$ of firms' outstanding shares were owned by Changzhou Bureau of State Assets Management, a government agency in charge of state-owned assets in the Changzhou region. The same structure (Figure 1) is reported in the 2001 annual report, suggesting that there was no change in organizational structure over the period of 1994-2001. In this case, the ultimate owner is a local government and the extent of the pyramidal structure is one layer - the local government directly controls the company. Figure 2 shows the structure of the Guangzhou Pearl River Industrial Development Co. that went public in 1993. Although its organizational structure was not disclosed in the IPO year, we assume that the firm's structure was the same as that in 2001, since we confirm that there has been no change in controlling ownership since the IPO. The 2001 annual report shows that the company is directly owned by Guangzhou Pearl River Industrial Group and Guangzhou Bureau of State Asset Management through holdings of 61.51 and $6.83 \%$ of outstanding shares, respectively. In turn, Guangzhou Pearl River Industrial Group Co. is wholly owned by Guangzhou Bureau of State Assets Management. Thus, Guangzhou Bureau of State Assets Management, which represents the local government, is the ultimate owner and the number of pyramidal layers is two - the number of layers of the longest pyramidal chain.

Using the above method, we systematically measure the extent of corporate pyramids controlling the publicly traded firms in our sample. 
Table 1 reports the sample firm's number of pyramidal layers. Note that our sample and the reported statistics pertain to the publicly traded firms at their IPO year and not the intermediate-layer firms. Among the 742 sample firms, $200(27 \%)$ are associated with only one corporate layer, suggesting that they are directly controlled by their ultimate controlling owners; $452(61 \%)$ are linked with their controlling owners through two-layer pyramids; $82(11 \%)$ are linked with their controlling owners through three-layer pyramids; and $8(1 \%)$ are linked with their controlling owners through pyramids of four or more layers. Prior to 1995, the single-layer pyramids are the dominant ownership structure. After that, multiple-layer pyramids become prevalent.

Despite the extensive use of pyramidal structures, Chinese-listed firms' voting rights and cash flow rights show almost no divergence, with a mean ratio of cash flow rights to voting rights of $0.97 .{ }^{4}$ The lack of separation between voting rights and cash flow rights of Chinese pyramids reflects state regulations prohibiting local governments from freely selling shares of the companies that they directly or indirectly control. Equity financing is therefore unlikely to be the primary driver of pyramidal structures in China.

\subsection{Measuring the Determinants of Corporate Pyramids}

As discussed in Section 2, the extent of corporate pyramids, and in turn of the delegation of firm decision rights, depends on the intervening incentives of controlling owners (local governments) and the degree of discipline provided by local markets and legal systems. Our local regions include all Chinese provinces as well as the autonomous regions and municipalities that are given provincial-level status. In this subsection, we discuss region-level empirical measures that capture the short- and long-term incentives of local governments and the disciplinary effects of market and legal institutions. We also discuss their predicted relations with the extent of corporate pyramids. Appendix Table A.2. provides definitions for these variables and their data sources. Appendix Table A.3. lists values for these variables by region.

3.3.1 Local Government Incentives. We employ several region-level variables as proxies for local governments' incentives to intervene in firm decisions. To capture a local government's short-run incentives, we use the unemployment rate of the region under the jurisdiction of the local government and a dummy variable that equals 1 if the local government's fiscal balance (fiscal revenue minus government expenditures scaled by regional gross domestic product [GDP]) is within the top quartile of the

4. The controlling owner's voting rights are given by the ownership percentage at the weakest link of the pyramidal chain, while the owner's cash flow rights are estimated by multiplying the ownership percentage of each link across the chain (La Porta et al. 1999; Claessens et al. 2002). 
Table 2. Principal Component Analysis (PCA) for Institutional and Incentive Variables

\begin{tabular}{lrl}
\hline Factor & Component loading & Proportion of variance (\%) \\
\hline Aggregate Incentive & & 54 \\
Unemployment & -0.647 & \\
Fiscal surplus & 0.564 & \\
R\&D & 0.512 & 74 \\
Aggregate institutions & & \\
Marketization & 0.385 & \\
Legal environment & 0.424 & \\
Protection for property rights & 0.367 & \\
Market deregulation & 0.437 & \\
FDI & 0.422 & \\
Openness & 0.411 & \\
\hline
\end{tabular}

This table provides results from PCA of three incentive variables (Unemployment, Fiscal Surplus, and R\&D) and six institutional variables (Marketization, Legal Environment, Protection of Property Rights, Market Deregulation, FDI, and Openness) as defined in Appendix Table A.2. Aggregate Incentive, which captures $54 \%$ of total variance, is the only factor with an eigenvalue greater than one from the PCA of incentive variables. Aggregate institutions, which captures $74 \%$ of the total variance, is the only factor with an eigenvalue greater than one from the PCA of institutional variables.

sample, and zero otherwise. We lag Unemployment and Fiscal Surplus by one year to mitigate potential endogeneity concerns. To capture the local government's long-run incentives, we use the local government's total research and development (R\&D) expenditures for the entire region scaled by regional GDP. We have only one year of data for $R \& D$ Expenditures, which is fixed over our sample period. Based on these three variables, we construct the factor score Aggregate Incentive, which satisfies the Kaiser criterion using principal component analysis. We employ this factor score in our regression analysis. ${ }^{5}$ Table 2 shows that this factor score correlates negatively with unemployment and positively with fiscal surplus and R\&D expenditures, capturing $54 \%$ of the total variance of the principal component analysis. We expect Aggregate Incentive (the factor score) to correlate positively with a controlling owner's (local government's) incentive for building pyramids.

3.3.2 Market and Legal Institutions. We use six region-level variables to proxy for the degree of development of China's regional market and legal institutions. The first three variables come from the National Economic Research Institute (NERI) Marketization Index of China's provinces in Fan and Wang (2001), which was sponsored by NERI and the China Reform Foundation. The first NERI variable is the marketization index, which captures the overall level of market development, including the degree of market competition and government intervention. The second variable is a legal environment index that measures the

5. The effect of each individual incentive variable on the emergence of pyramids is available at http://ihome.cuhk.edu.hk/ b109671. 
development of market intermediaries and the degree to which producers' and consumers' interests are protected. The third variable is an index of property rights protection, which measures the economic significance of all the legal cases in the region relative to the region's GDP and the court's efficiency in resolving these cases. Appendix Table A.2. presents a detailed description of these variables.

Our fourth proxy for the degree of institutional development is the deregulation index constructed by Demruger et al. (2002), which captures the extent to which a region receives preferential policies from the central government. A higher value of the index suggests more deregulation in the regions' markets.

The last two variables measure the influence of foreign investment and trade on regional market development: the region's annual flow of foreign direct investment scaled by the GDP of the region, FDI, which captures the influence of foreign investment, and the region's total foreign imports and exports scaled by the GDP of the region, and Openness, which captures the influence of foreign trade. We lag FDI and Openness by one year to mitigate potential endogeneity concerns. However, we have only one period's worth of data for the other institutional variables, which means that these variables are taken to be constant over time. As before, we use these six variables to construct a factor score using principal component analysis. Table 2 shows that this linear factor score, termed Aggregate Institutions, correlates positively with the six institutional variables by construction, capturing $74 \%$ of the total variance from the principal component analysis. We employ this aggregate variable in our regression analysis. ${ }^{6}$ We expect Aggregate Institutions, a proxy for the extent of local market and legal discipline, to correlate positively with the extent of a listed company's pyramiding.

3.3.3 Control Variables. We include several control variables in the model of corporate pyramids. Firm Size is the natural logarithm of total assets. Financial Leverage is the total liabilities divided by the total sales. Growth is the market-to-book ratio, or market value of common equity divided by book value of equity, with the market price measured at the end of the first year during which the firm went public. We winsorize these variables at the top and bottom $1 \%$ to mitigate the effects of outliers. In addition, we include a regulatory industry dummy variable that equals 1 if the firm operates in a heavily regulated sector (i.e., natural resources, electricity, finance, and public utilities), and zero otherwise. Data for constructing these variables are available from the China Stock Market and Accounting Research database.

We expect that controlling owners of larger firms, high growth firms, or firms with a larger debt burden are more likely to decentralize decision

6. The effect of each individual institutional variable on the emergence of pyramid is available at http://ihome.cuhk.edu.hk/ b109671. 
rights to local managers because such firms are more difficult to manage. These firms are therefore predicted to have more extensive pyramidal layers than otherwise similar firms. In contrast, we expect firms in heavily regulated sectors to be less decentralized and hence have fewer pyramidal layers, because government owners tend to retain control of strategically important firms.

\subsection{Regression Results}

We use the following regression model for our analysis:

$$
\begin{aligned}
\text { Layers }= & \alpha+\beta_{1} * \text { Aggregate Incentives }+\beta_{2} * \text { Aggregate Institutions } \\
& +\beta_{3} * \text { Firm Size }+\beta_{4} * \text { Financial Leverage }+\beta_{5} * \text { Growth } \\
& +\beta_{6} * \text { Regulated Industry }+ \text { Year Fixed Effects }+\varepsilon
\end{aligned}
$$

Layers are the number of pyramidal layers and the independent variables are defined in the preceding section. Since the values of the dependent variable are discrete and bounded between 1 and 5, we employ an ordered probit model in the regression analysis. The proportional odds assumption, which is that the relationship between any two pairs of groups is statistically the same, is imposed on this model. To control for effects of regional wealth and growth, we include provincial GDP level and GDP growth as additional independent variables. While the results for the incentive and institutional development variables remain unchanged, we fail to find significant effects of the two GDP variables. We therefore exclude them from our primary regression analysis. In addition to the regional variables and the control variables, we include eight-year dummy variables for 1994-2001 (not reported). Each year dummy equals 1 , if the firm went public during that year, and zero otherwise. $^{7}$

Table 3 reports the regression results. Both Aggregate Incentive and Aggregate Institutions are positive and statistically significant, suggesting that controlling owner (local government) incentives and the quality of local market and legal institutions significantly affect the extent of a firm's pyramid structure. Across the table columns, we see that the effects of the firm-level variables are generally in the expected direction. In particular, corporate pyramiding is positively related to Firm Size, Financial Leverage, and Growth, although only the coefficients on Firm Size and Growth are significant. We expect that the government is less likely to decentralize the decision rights to the firms in the heavily regulated industries. However, we do not find such an effect in the regression results.

7. We do not include regional fixed effects because four of the six institutional variables and one incentive variable do not vary over time in our sample period. The remaining institutional and incentive variables also tend to be sticky over time. 
Table 3. Regression Results of the Determinants of Corporate Pyramids: Incentive and Institutional Determinants

\begin{tabular}{lccc}
\hline & $\begin{array}{l}\text { (1) Incentive } \\
\text { Determinant }\end{array}$ & $\begin{array}{l}\text { (2) Institutional } \\
\text { Determinant }\end{array}$ & $\begin{array}{l}\text { (3) Incentive and } \\
\text { Institutional } \\
\text { Determinants }\end{array}$ \\
\hline Aggregate incentive & $0.147^{* * *}(3.81)$ & & $0.079^{* *}(2.17)$ \\
Aggregate institutions & & $0.132^{* * *}(3.98)$ & $0.115^{* *}(3.01)$ \\
Firm size & $0.172^{*}(1.87)$ & $0.146(1.60)$ & $0.134(1.46)$ \\
Financial leverage & $0.020(0.59)$ & $0.009(0.25)$ & $0.012(0.34)$ \\
Growth & $0.043^{* *}(1.99)$ & $0.034(1.55)$ & $0.033(1.47)$ \\
Regulated industry & $0.119(1.27)$ & $0.068(0.75)$ & $0.071(0.80)$ \\
$N$ & 742 & 739 & 739 \\
Pseudo $R^{2}$ & 0.089 & 0.102 & 0.105 \\
\hline
\end{tabular}

This table reports regression results of the aggregated incentive and institutional determinants of pyramidal organizational structure. The dependent variable is the number of pyramidal layers between the controlling owner and the listed firm. Independent variables include Aggregate Incentive and Aggregate Institutions, as defined in Table 2. Control variables include firm size that is the logarithm of total assets at the end of the IPO year; financial leverage that is the ratio of total liabilities to sales at the end of the IPO year; growth that is the ratio of market-to-book equity at the end of the IPO year; and regulated industry that equals 1 if the firm is in a highly regulated industry and zero otherwise. All regressions include year dummy variables but are not reported. The firm-level independent variables with continuous values are winsorized at the top $1 \%$ level. Ordered Probit is used in the regressions with clustering error by province. Absolute $Z$-values are in parentheses. Asterisks denote the level of statistical significance: ${ }^{\star \star \star} 1 \%$, ${ }^{*} 5 \%$, and ${ }^{*} 10 \%$.

\subsection{Endogeneity Issues}

We perform several robustness checks. Although pyramids, as we have argued, may insulate firm managers from government interference and hence improve efficiency and professionalism, in theory it may also be the case that efficient managers have sufficient bargaining power to compel the state to let them siphon off firm cash flows through pyramid structures, as part of the rents their talent is due in an otherwise competitive setting. We discussed this issue with an official in Beijing responsible for monitoring reforms of state assets. The official explained that, by law, managers in China do not have such power; instead, setting up a subsidiary and transferring state assets into the subsidiary requires approval by a state asset management bureau that manages the assets, or by a local government that is the controlling owner of the parent company of the assets. In addition, from our survey results presented below, we find that decision rights related to capital investment and executive appointments are retained by the government. Nevertheless, as we are unable to empirically disentangle the different possibilities, we avoid claiming causality in our hypotheses.

Another concern is that the relation between pyramids and institutional development may be spurious. For example, if the number of SOEs in a region with strong institutions is larger than that in a region with weak institutions, then even a random allocation of firms across pyramids and direct ownership structures should produce the result that good institutions are associated with more pyramids. We find that the correlation 
coefficient between the institutions variable and the number of SOEs is indeed significantly positive (55\%). However, the correlation coefficient between the number of pyramid layers and the number of SOEs is negative $(-5 \%)$. When we include the number of SOEs as an additional independent variable in the regressions, we find either insignificant or significantly negative coefficients across the various regression specifications; all other results remain unchanged. We do not tabulate these results to save space.

The relations between corporate pyramiding and the regional factors of interest are still subject to several alternative interpretations. Firms gaining autonomy might pressure governments to improve market and legal infrastructures. In contrast, local governments that still have tight control over their firms might obstruct legal and market development in the region to protect their interests (Shleifer and Vishny 1994; Morck et al. 2000). To mitigate these reverse causality concerns and other potential spurious correlations, we employ two-stage regression analysis. In the first stage, we regress Aggregate Institutions, the principal component analysis factor based on the six institutional variables, on three instrumental variables: Seaports, Commercial Ports, and Leased Territories.

Seaports is the number of seaports in the region during our sample period. This variable measures each region's access to the sea, which should influence its institutional development. However, the formation of corporate pyramids in a region should not affect the region's access to the sea, which is primarily determined by its geography. The next two variables, Commercial Ports and Leased Territories, capture the influence of foreign institutional development in a region. Commercial Ports is a dummy variable that equals 1 , if the region's sea or inland river ports were forced open to foreigners as treaty ports after the first Opium War in 1842 during the Qing Dynasty, ${ }^{8}$ and zero otherwise. Similarly, Leased Territories is a dummy variable that equals 1 , if the region leased territories to foreigners after the first Opium War in 1842 during the Qing Dynasty. Since these treaty ports and leased territories were opened to foreigners by exogenous forces over 100 years ago, corporate pyramids cannot have had any direct impact on their creation. However, like colonization, the establishment of ports and territories that were influenced

\footnotetext{
8. After the first Opium War in 1842, China was forced to sign several treaties with foreigners to open treaty ports or set up leased territories. The period between 1842 and 1943 (or alternatively, 1842-1949) is referred to by Fairbank and Goldman (1992) as the Treaty Century, which was characterized by China's increasing openness to foreign contact. These treaty ports are located in (1) Fujian, Guangdong, Shanghai, and Zhejiang (Treaty of Nanjing 1842), (2) Fujian, Hainan, Hubei, Guangdong, Jiangsu, Liaoning, and Shandong (Treaty of Tianjin 1858), (3) Tianjin and Xinjiang (Treaty of Beijing 1860), (4) Anhui, Hubei, Guangxi, and Zhejiang (Treaty of Yantai 1876), and (5) Chongqing, Hubei, and Zhejiang (Treaty of Maguan 1895). The locations of the leased territories include Tianjin (1860), Shanghai (1845), Jiangsu (1863), Zhjiang (1896), Anhui (1877), Jiangxi (1861), Fujian (1861), Shandong (1889), Guangdong (1857), Chongqing (1901), and Hubei (1861).
} 
or governed by foreigners was likely to have had a long-term impact on the development of local market and legal institutions (Acemoglu et al. 2001). In addition, since the direct influence of the number of seaports, and the presence of leased ports and territories in a region, on firm pyramiding decisions works through institutional development, these instrumental variables control not only for potential reverse causality but also for spurious correlation between the institutional factors and the pyramid variable.

In addition to the instrumental variables, we include the firm control variables for size, leverage, and growth, as well as the regulatory industry dummy variable. Since we run the first-stage regressions at the regional level, we calculate the firm control variables as regional averages.

Compared with Aggregate Institutions, we are less concerned about endogeneity between the Aggregate Incentive variable and firms' pyramiding decisions. For example, governments' high incentives for intervention will lead to less extensive pyramids. But the reverse causality argument suggests that fewer pyramidal layers will solve fiscal and social problems, reducing governments' incentives to intervene, and therefore yielding longer pyramids. The findings in Tables 2 and 3 are consistent with our prediction but not with the reverse causality argument.

In the second stage, we employ the predicted value of Aggregate Institutions, called Predicted Institutional Factor, estimated from the first-stage regressions to replace Aggregate Institutions in the pyramid determination regression in model (3) of Table 3.

Table 4 reports the results of the first- and second-stage regressions. The coefficients on Sea Ports and Leased Territories in the first-stage regression are significantly positive, whereas the coefficient on Commercial Ports is negative but statistically insignificant. The adjusted $R^{2}$ of the first-stage regressions is quite high $(83 \%)$. In the second stage, the coefficient on Aggregate Incentive remains positive and statistically significant. The coefficient on Predicted Institutional Factor is positive and statistically significant.

\section{Pyramids and Firm Performance}

In this section, we analyze the relations between pyramidal structures and managerial professionalism and firm performance as measured by Tobin's Q, employment efficiency, total factor productivity, and accounting profitability. We do not intend to use these analyses for establishing a causal relation between pyramid structures and efficiency. This is because the government can delegate decision rights to capable firm managers or capable firm managers can bargain with the government for the decision rights. In addition, although we analyze the relation between pyramids and performance after controlling for institutional variables that potentially affect both pyramids and performance, we are unable to claim that we have fully accounted for pyramid-related selection effects. 
Table 4. Two-stage Regression Results of the Determinants of Corporate Pyramids

\begin{tabular}{|c|c|c|}
\hline & First stage & Second stage \\
\hline Number of Sea Ports & $0.206^{\star \star \star *}(9.95)$ & \\
\hline Commercial Port & $-0.088(0.56)$ & \\
\hline Leased territories & $1.575^{\star \star \star}(10.37)$ & \\
\hline Aggregate Incentive & & $0.103^{\star * *}(2.68)$ \\
\hline Predicted Institutional Factor & & $0.121^{\star * *}(3.41)$ \\
\hline Total assets & $2.169^{\star * \star}(7.77)$ & $0.128(1.38)$ \\
\hline Leverage & $2.729^{\star \star \star}(11.69)$ & $0.012(0.33)$ \\
\hline Growth & $-0.062(0.49)$ & 0.035 (1.57) \\
\hline Regulated industry & $0.236(0.18)$ & $0.072(0.81)$ \\
\hline Constant & $-48.256^{\star \star \star}(8.25)$ & \\
\hline$N$ & 215 & 739 \\
\hline Adjusted/Pseudo $R^{2}$ & 0.83 & 0.11 \\
\hline
\end{tabular}

This table presents two-stage regression results of the determinants of pyramidal organizational structure. The dependent variable in the first-stage OLS regression is Aggregate Institutions, which is the PCA factor score of the six institutional variables (Marketization, Legal Environment, Property Rights, Deregulation, FDI, and Openness), all defined in Appendix Table A.2. The independent variables include Seaports, which is the number of seaports in the region, Commercial Ports that equals 1 if the region had treaty ports forced open to foreigners in the Qing Dynasty, and zero otherwise, and Leased Territories that equals 1 if the region had territories leased to foreigners in the Qing Dynasty, and zero otherwise. Additional control variables in the first stage include Total Assets that is the mean of log value of total assets of all sample firms in the region; Leverage that is the mean of ratio of total liability to total assets of all sample firms in the region; Growth that is the mean value of market-to-book equity ratio of all sample firms in the region; and Regulated industry that is the percentage of firms in regulated industries in the region. In the second stage, the dependent variable is the number of pyramidal layers. Independent variables include Aggregate Incentive: the PCA factor score of the three incentive variables; Predicted Aggregate Institutions: the predicted value of Aggregate Institutions from the first-stage model; Firm Size: the logarithm of total assets at the end of the IPO year; Financial Leverage: the ratio of total liabilities to sales at the end of the IPO year; Growth that is market-to-book equity ratio at the end of IPO year; and Regulated Industry that equals 1 if the firm is in a highly regulated industry, and zero otherwise. All the financial variables used in first stage are the mean of that of all firms from the region. All regressions include year dummy variables but are not reported. The firm-level independent variables with continuous values are winsorized at the top $1 \%$ level. Ordered Probit is estimated in the second-stage regressions with clustering error by province. Absolute $t$-values are in parentheses of the first-stage results, and absolute Z-values are in parentheses of the second-stage results. Asterisks denote the level of statistical significance: ${ }^{\star \star *} 1 \%,{ }^{\star \star} 5 \%$, and ${ }^{\star} 10 \%$.

\subsection{Managerial Professionalism}

If a pyramid structure is built to separate an SOE from political interference, we should observe a high degree of managerial professionalism in decentralized firms. Moreover, managers of a decentralized firm may have less affiliation with the government than managers of a firm that is not decentralized, assuming that the former face less intervention by the government or pursue arm's-length competition rather than depend on government resources.

Focusing first on a company's top management, we define Professionalism as a dummy variable equal to 1 , if the CEO or chairman of a company is a CPA, has a law degree, or has other above-college education, and otherwise zero. We define Political Connection as a dummy variable equal to 1 , if the CEO or chairman has previously served as a bureaucrat, and otherwise zero (Fan et al. 2007). We regress 
Table 5. Pyramidal Structures and Management Professionalism: CEO and Chairman

\begin{tabular}{|c|c|c|c|c|}
\hline & \multicolumn{2}{|c|}{ Professionalism } & \multicolumn{2}{|c|}{ Political connection } \\
\hline & $\begin{array}{l}\text { (1) Without } \\
\text { Incentive and } \\
\text { Institutional } \\
\text { Variables }\end{array}$ & $\begin{array}{l}\text { (2) With } \\
\text { Incentive and } \\
\text { Institutional } \\
\text { Variables }\end{array}$ & $\begin{array}{l}\text { (3) Without } \\
\text { Incentive and } \\
\text { Institutional } \\
\text { Variables }\end{array}$ & $\begin{array}{l}\text { (4) With } \\
\text { Incentive and } \\
\text { Institutional } \\
\text { Variables }\end{array}$ \\
\hline Pyramid & $0.554^{\star \star \star}(2.84)$ & $0.532^{\star \star \star}(2.97)$ & $0.085(0.49)$ & $0.072(0.44)$ \\
\hline Aggregate Incentive & & $0.173(1.13)$ & & $0.071(0.83)$ \\
\hline Aggregate Institutions & & $-0.066(1.01)$ & & $-0.080(0.95)$ \\
\hline Financial Leverage & $-0.052(0.80)$ & $-0.043(0.64)$ & $0.085(0.77)$ & $0.073(0.67)$ \\
\hline Firm Size & $0.065(0.34)$ & $0.062(0.34)$ & $-0.133(1.06)$ & $-0.146(1.09)$ \\
\hline Growth & $-0.015(0.38)$ & $-0.019(0.47)$ & $-0.071(1.38)$ & $-0.077(1.50)$ \\
\hline Regulated Industry & $2.034^{* * *}(3.21)$ & $2.030^{* * *}(3.22)$ & ) $0.466(1.03)$ & $0.467(1.03)$ \\
\hline Constant & $-1.540(0.40)$ & $-1.496(0.37)$ & $3.231(0.37)$ & $3.553(1.28)$ \\
\hline$N$ & 625 & 622 & 625 & 622 \\
\hline Pseudo $R^{2}$ & 0.097 & 0.100 & 0.062 & 0.063 \\
\hline
\end{tabular}

This table presents the regression result of professionalism and political connection of CEO and Chairman the first year after IPO year on Pyramid, the number of pyramidal layers between controlling shareholder and listed firm. The dependent variable is Professionalism, which equals 1 if CEO or Chairman of the company has a CPA, lawyer certification or above college education, and zero otherwise, and Political Connection that equals 1 if CEO or Chairman has government working experience, and zero otherwise in Models (1-4), respectively. Additional independent variables include Firm Size: the logarithm value of total assets; Financial Leverage: the ratio of total liabilities to sales; Growth: the market-to-book equity ratio; and Regulated Industry that equals 1 if the firm is in a highly regulated industry, and zero otherwise. All continuous variables are winsorized at the top and bottom $1 \%$ levels. The independent variables are measured at the end of first year after IPO. Year dummy variables are included but not reported. A logistic model is applied in Models (1) and (2), where absolute Z-values are reported in parentheses. The logistic model is estimated with clustering error by province. Asterisks denote the level of statistical significance: ${ }^{*} 10 \%$, ${ }^{\star} 5 \%$ and ${ }^{* \star \star} 1 \%$.

Professionalism and Political Connection on Pyramid and the usual control variables.

Table 5 reports logit regression results. We find that Pyramid is strongly positively related to Professionalism, and the relation is robust to controlling for Aggregate Incentives and Aggregate Institutions. In contrast, the relation between Pyramid and Political Connection is insignificant.

Next, we examine the relations between pyramids and the professionalism and political connectedness of all members of a firm's board of directors. We redefine Professionalism as the percentage of directors that are a CPA, have a law degree, or have other above-college education. We redefine Political Connection as the percentage of directors who have previously served as government bureaucrats.

Table 6 reports ordinary least square regression results. Again, we find that Pyramid is significantly positively related to Professionalism, but is insignificantly related to Political Connection.

The above results lend support to the view that pyramidal organizational structures are positively associated with the professionalization of firm management. We find no support, however, for the view that pyramids affect the political connectedness of firm managers. 
Table 6. Pyramidal Structures and Management Professionalism: Board of Directors

\begin{tabular}{|c|c|c|c|c|}
\hline & \multicolumn{2}{|c|}{ Professionalism } & \multicolumn{2}{|c|}{ Political connection } \\
\hline & $\begin{array}{l}\text { (1) Without } \\
\text { Incentive and } \\
\text { Institutional } \\
\text { Variables }\end{array}$ & $\begin{array}{l}\text { (2) With } \\
\text { Incentive and } \\
\text { Institutional } \\
\text { Variables }\end{array}$ & $\begin{array}{l}\text { (3) Without } \\
\text { Incentive and } \\
\text { Institutional } \\
\text { Variables }\end{array}$ & $\begin{array}{l}\text { (4) With } \\
\text { Incentive and } \\
\text { Institutional } \\
\text { Variables }\end{array}$ \\
\hline Pyramid & $0.077^{\star * *}(4.48)$ & $0.080^{* * *}(4.33)$ & $0.014(0.81)$ & $0.016(0.81)$ \\
\hline Aggregate Incentive & & $0.002(0.15)$ & & $0.004(0.68)$ \\
\hline Aggregate Institutions & & -0.007 (1.33) & & $-0.005(0.80)$ \\
\hline Financial Leverage & $-0.004(0.67)$ & $-0.003(0.67)$ & 0.009 (0.95) & $0.010(1.00)$ \\
\hline Firm Size & $0.083^{* * *}(1.09)$ & $0.086^{* * *}(1.09)$ & $-0.003(0.19)$ & $-0.001(0.19)$ \\
\hline Growth & $0.015^{\star * *}(3.60)$ & $0.016^{* * *}(4.00)$ & $0.001(0.22)$ & $0.002(0.59)$ \\
\hline Regulated Industry & $0.084^{\star \star}(2.38)$ & $0.085^{\star \star}(2.38)$ & $0.156^{\star \star \star}(4.25)$ & $0.155^{\star \star \star}(4.20)$ \\
\hline Constant & $-1.254^{\star \star \star}(1.28)$ & $-1.314^{\star \star \star}(1.28)$ & $0.275(1.28)$ & $0.233(1.28)$ \\
\hline$N$ & 645 & 642 & 645 & 642 \\
\hline Adjusted $R^{2}$ & 0.19 & 0.20 & 0.11 & 0.11 \\
\hline
\end{tabular}

This table presents the OLS regression results of Tobin's $Q$, measured as the sum of market value of equity and book value of liabilities, all divided by total assets at the end of the IPO year, on Pyramid, which is the number of pyramidal layers between the listed company and the controlling owner. The control variables include: Firm Size that is the logarithm of total assets; Financial Leverage that is the ratio of total liabilities to sales; Sales Growth that is the two-year average annual growth in firm sales prior to the IPO; and Regulated Industry that equals 1 if the firm is in a highly regulated industry, and zero otherwise; Aggregate Incentive: the PCA factor scores extracted from government variables; Aggregate Institutions: the PCA factor scores extracted from regional institutional variables. All the independent variables are measured at the end of the IPO year and the continuous variables are winsorized at the top and bottom $1 \%$ levels. Year dummy variables are included but not reported. The OLS model is estimated with clustering error by province. Absolute $t$-values are in parentheses. Asterisks denote the level of statistical significance: ${ }^{*} 10 \%$, ${ }^{*} 5 \%$, and ${ }^{* *} 1 \%$.

\subsection{Tobin's $Q$}

We estimate Tobin's $Q$ as the market value of common stock plus the book value of total liabilities, divided by the book value of total assets as of the last day of the IPO fiscal year. This stock-based measure is useful for examining whether minority shareholders account for the potential costs and benefits of the pyramid structure. ${ }^{9}$ We regress Tobin's $Q$ on Pyramid, Firm Size, Sales Growth, Financial Leverage, the industry dummy variable, and the year dummy variables, where Sales Growth is the two-year average annual growth in sales prior to the firm's IPO. Due to missing pre-IPO sales data for some companies, we perform this regression on the 562 firms with nonmissing data. Table 7 reports the regression results. The coefficient on Pyramid is positive and statistically significant at the $10 \%$ level (column (1)), suggesting that firms controlled by more pyramidal layers have higher value. The relation becomes statistically

9. Minority interests in Chinese SOEs are significant. The average tradable shares of the companies in the sample account for almost $28 \%$ of the total outstanding shares. Among the sample firms, almost $40 \%$ have at least one nongroup-affiliated block holder with $>5 \%$ ownership. Thus, this stock-based measure reflects the valuation by minority shareholders and their response to the emergence of stock pyramids. 
Table 7. Pyramidal Structures and Tobin's $Q$

\begin{tabular}{lcc}
\hline & $\begin{array}{c}\text { (1) Without Incentive and } \\
\text { Institutional Variables }\end{array}$ & $\begin{array}{c}\text { (2) With Incentive and } \\
\text { Institutional Variables }\end{array}$ \\
\hline Pyramid & $0.086^{*}(1.76)$ & $0.058(1.09)$ \\
Aggregate Incentive & & $0.025(0.99)$ \\
Aggregate Institutions & & $0.040^{*}(1.80)$ \\
Sales Growth & $0.846^{\star \star *}(5.27)$ & $0.839^{\star \star *}(5.00)$ \\
Financial Leverage & $-0.076(0.86)$ & $-0.079(0.88)$ \\
Firm Size & $-0.556^{\star \star *}(8.17)$ & $-0.582^{\star \star *}(8.62)$ \\
Regulated Industry & $0.169(1.12)$ & $0.143(0.95)$ \\
Constant & $13.488^{\star \star *}(10.75)$ & $13.982^{\star \star *}(11.25)$ \\
Observations & 562 & 559 \\
Adjusted $R^{2}$ & 0.34 & 0.34 \\
\hline
\end{tabular}

This table presents the OLS regression results of Tobin's Q, measured as the sum of market value of equity and book value of liabilities, all divided by total assets at the end of the IPO year, on Pyramid, which is the number of pyramidal layers between the listed company and the controlling owner. The control variables include: Firm Size that is the logarithm of total assets; Financial Leverage that is the ratio of total liabilities to sales; Sales Growth that is the two-year average annual growth in firm sales prior to the IPO; and Regulated Industry that equals 1 if the firm is in a highly regulated industry, and zero otherwise; Aggregate Incentive: the PCA factor scores extracted from government variables; Aggregate Institutions: the PCA factor scores extracted from regional institutional variables. All independent variables are measured at the end of the IPO year and the continuous variables are winsorized at the top and bottom $1 \%$ levels. Year dummy variables are included but not reported. The OLS model is estimated with clustering error by province. Absolute $t$-values are in parentheses. Asterisks denote the level of statistical significance: ${ }^{*} 10 \%,{ }^{\star *} 5 \%$, and ${ }^{\star \star \star} 1 \%$.

insignificant, however, when we further control for Aggregate Incentive and Aggregate Institutions (column (2)).

\subsection{Employment Efficiency}

State-owned firms typically aim to maintain employment even at the expense of the firm efficiency. However, we expect decentralized firms to be less burdened by such employment objectives than firms more tightly controlled by the state. We therefore expect the employment efficiency of a firm to be positively related to the extent of the firm's pyramidal structure. Based on 617 IPO-year firm observations, in column (1) of Table 8 , we find such a relation when we regress the ratio of the number of employees to firm sales, an inverse measure of labor efficiency, on Pyramid, controlling for industry, year, and firm effects. Further, we find that the relation between pyramidal structure and employment efficiency is robust to the inclusion of Aggregate Incentive and Aggregate Institutions as additional control variables, suggesting that this relation is not spuriously induced by incentive or institutional effects.

\subsection{Total Factor Productivity}

We next analyze the relation between a firm's pyramidal layers and its total factor productivity based on a log-linear Cobb-Douglas production function. Output is the logarithm of total sales in each of the three years after the IPO year. The two input factors are Labor and Capital, measured 
Table 8. Pyramidal Structures and Employment Efficiency

\begin{tabular}{lcl}
\hline & $\begin{array}{l}\text { (1) Without Incentive and } \\
\text { Institutional Variables }\end{array}$ & $\begin{array}{l}\text { (2) With Incentive and } \\
\text { Institutional Variables }\end{array}$ \\
\hline Pyramid & $-1.409^{\star * *}(2.88)$ & $-1.161^{\star * *}(2.93)$ \\
Aggregate incentive & & $-0.034(0.17)$ \\
Aggregate institutions & & $-0.662(4.48)$ \\
Financial leverage & $3.779^{\star * *}(3.02)$ & $3.802^{\star * *}(3.10)$ \\
Firm size & $-3.726^{\star * *}(5.97)$ & $-3.372^{\star * *}(5.97)$ \\
Growth & $-0.569^{\star * *}(3.48)$ & $-0.481^{\star * *}(3.48)$ \\
Regulated industry & $0.294(0.26)$ & $0.689(0.62)$ \\
Constant & $86.943^{\star * *}(6.79)$ & $79.797^{\star * *}(6.09)$ \\
$N$ & 617 & 614 \\
Adjusted $R^{2}$ & 0.19 & 0.20 \\
\hline
\end{tabular}

This table presents OLS regression results of Employment Efficiency, measured as the number of employees scaled by sales in the IPO year, on Pyramid, which is the number of pyramidal layers between the listed company and the controlling owner. Control variables include: Firm Size that is the logarithm of total assets; Financial Leverage that is the ratio of total liabilities to sales; Growth that is the market-to-book equity ratio; and Regulated Industry that equals 1 if the firm is in a highly regulated industry, and zero otherwise; Aggregate Incentive: the PCA factor scores extracted from government variables; Aggregate Institutions: the PCA factor scores extracted from regional institutional variables. All variables are measured at the end of the IPO year and all the continuous variables are winsorized at the top and bottom $1 \%$ levels. Year dummy variables are included but not reported. Absolute $t$-values are in parentheses. The OLS model is estimated with clustering error by province. Asterisks denote the level of statistical significance: ${ }^{*} 10 \%,{ }^{*} 5 \%$, and ${ }^{* *} 1 \%$.

as the logarithm of the total number of employees in the IPO year ${ }^{10}$ and the logarithm of total fixed assets in each of the three years after the IPO. In addition, we include Pyramid in the production model to capture any productivity difference due to pyramidal structure. We also include the regulatory industry dummy variable and year dummy variables (not reported) in the regression.

Table 9 reports the regression results. Consistent with prior research, the coefficients on Labor and Capital are positive and highly statistically significant. The coefficient on Pyramid is positive and statistically significant at the $10 \%$ level. This positive relation is robust to controlling for Aggregate Incentive and Aggregate Institutions.

\subsection{Profitability}

We next investigate the relation between pyramid structures and firm accounting profitability as measured by return on sales $(R O S)$ and return on assets $(R O A)$. After controlling for firm fundamentals, we find that the pyramid variable is statistically positively related to $R O S$, but not to $R O A$, as reported in columns (1) and (3) in Table 10. After further controlling for the institutional variables, the pyramid variable is significantly related to both ROS and ROA (columns (2) and (4)). Overall, the result in Table 10 suggests a positive association between pyramid structures and accounting profitability.

10. Since post-IPO employee numbers are unavailable, we assume these numbers are similar to those in the IPO year. 
Table 9. Pyramidal Structures and Total Factor Productivity

\begin{tabular}{lcc}
\hline & $\begin{array}{c}\text { (1) Without Incentive and } \\
\text { Institutional Variables }\end{array}$ & $\begin{array}{c}\text { (2) With Incentive and } \\
\text { Institutional Variables }\end{array}$ \\
\hline Pyramid & $0.088^{*}(1.72)$ & $0.075^{*}(1.75)$ \\
Aggregate incentive & & $0.069^{* *}(2.13)$ \\
Aggregate institutions & & $0.048(1.40)$ \\
Labor & $0.197^{* * *}(5.46)$ & $0.202^{* * *}(6.47)$ \\
Capital & $0.513^{\star * *}(8.57)$ & $0.516^{\star * *}(9.34)$ \\
Regulated industry & $-0.588^{* * *}(6.40)$ & $-0.631^{* * *}(7.10)$ \\
Constant & $8.446^{\star * *}(8.35)$ & $8.333^{\star * *}(8.75)$ \\
Observations & 1922 & 1913 \\
Adjusted $R^{2}$ & 0.41 & 0.43 \\
\hline
\end{tabular}

This table presents OLS regression results of firm output, measured as the logarithm of sales in each of the three years after the IPO year; on Pyramid: the number of corporate layers between a listed company and a controlling owner; Labor: the logarithm of the number of employees at the end of the IPO year; Capital: the logarithm of total fixed assets; and Regulated Industry that equals 1 if the company is in a highly regulated industry, and zero otherwise; Aggregate Incentive: the PCA factor scores extracted from government variables; Aggregate Institutions: the PCA factor scores extracted from regional institutional variables. All of the continuous variables are winsorized at the top and bottom $1 \%$ levels. Year dummy variables are included but not reported. The OLS model is estimated with clustering error by firm and province. Absolute $t$-values are in parentheses. Asterisks denote the level of statistical significance: ${ }^{*} 10 \%,{ }^{*} 5 \%$, and ${ }^{* \star *} 1 \%$.

Table 10. Pyramidal Structure and Firm Profitability

\begin{tabular}{|c|c|c|c|c|}
\hline & $\begin{array}{l}\text { ROS } \\
\text { (1) Without } \\
\text { Incentive and } \\
\text { Institutional } \\
\text { Variables }\end{array}$ & $\begin{array}{l}\text { ROS } \\
\text { (2) With } \\
\text { Incentive and } \\
\text { Institutional } \\
\text { Variables }\end{array}$ & $\begin{array}{l}\text { ROA } \\
\text { (3) Without } \\
\text { Incentive and } \\
\text { Institutional } \\
\text { Variables }\end{array}$ & $\begin{array}{l}\text { ROA } \\
\text { (4) With } \\
\text { Incentive and } \\
\text { Institutional } \\
\text { Variables }\end{array}$ \\
\hline Pyramid & $0.018^{*}(1.73)$ & $0.021^{\star \star}(2.27)$ & $0.005(1.47)$ & $0.006^{\star}(1.77)$ \\
\hline $\begin{array}{l}\text { Aggregate } \\
\text { incentive }\end{array}$ & & $-0.008(1.77)$ & & $-0.002(0.67)$ \\
\hline $\begin{array}{l}\text { Aggregate } \\
\text { institutions }\end{array}$ & & $-0.006^{\star \star}(2.44)$ & & $-0.002^{\star \star}(1.98)$ \\
\hline $\begin{array}{l}\text { Financial } \\
\text { leverage }\end{array}$ & $0.007(0.85)$ & $0.007(0.83)$ & $-0.030^{\star \star \star}(11.97)$ & $-0.030^{\star \star \star}(11.75$ \\
\hline Firm size & $0.005(0.68)$ & $0.009(1.22)$ & $0.012^{\star * \star}(6.98)$ & $0.013^{\star * *}(7.27)$ \\
\hline Growth & $0.011^{* * *}(4.37)$ & $0.012^{* * *}(4.37)$ & $0.007^{\star \star \star}(6.49)$ & $0.008^{* * *}(7.24)$ \\
\hline $\begin{array}{l}\text { Regulated } \\
\text { industry }\end{array}$ & $0.148^{* * *}(8.90)$ & $0.151^{* * *}(9.01)$ & $0.016^{\star * *}(3.00)$ & $0.017^{\star \star *}(3.16)$ \\
\hline Constant & $-0.010(0.06)$ & $-0.090(0.57)$ & $-0.177^{\star \star \star}(4.93)$ & $-0.200^{\star * *}(5.13)$ \\
\hline Observations & 2224 & 2215 & 2224 & 2215 \\
\hline Adjusted $R^{2}$ & 0.32 & 0.33 & 0.43 & 0.44 \\
\hline
\end{tabular}

This table presents OLS regression results of profitability, measured as the ROS and ROA in the three years after $\mathrm{IPO}$, on Pyramid, which is the number of pyramidal layers between the listed company and the controlling owner. Control variables include: Firm Size that is the logarithm of total assets; Financial Leverage that is the ratio of total liabilities to sales; Growth that is the market-to-book equity ratio; and Regulated Industry that equals 1 if the firm is in a highly regulated industry, and zero otherwise; Aggregate Incentive: the PCA factor scores extracted from government variables; Aggregate Institutions: the PCA factor scores extracted from regional institutional variables. All variables are measured at the end of each of three years after IPO and all the continuous variables are winsorized at the top and the bottom $1 \%$ levels. Year dummy variables are included but not reported. The OLS model is estimated with clustering error by firm and province. Asterisks denote the level of statistical significance: ${ }^{*} 10 \%,{ }^{*} 5 \%$, and ${ }^{* * *} 1 \%$. 
In summary, the various analyses in this section provide consistent evidence that firms with more extensive pyramidal structures tend to be associated with greater managerial professionalism, employment efficiency, total factor productivity, and profitability/share value. These results lend additional support to our conjecture that pyramidal structures are associated with lower political interference and more empowered firm management relative to direct ownership structures.

\section{Survey Evidence}

Although our primary analyses above deliver results consistent with the argument that pyramids are associated with the delegation of firm decision rights, we have not provided any direct evidence that managers of pyramid-affiliated firms actually possess more firm decision rights than managers of firms directly linked to the government. To address this question, we conducted a survey of government officials in charge of state asset management.

The survey refers to two firms. Firm A is directly linked to the government, whereas Firm B is affiliated with a pyramid. All other aspects of the two firms are the same. We ask each respondent the following question: "As a major shareholder, do you intervene in managers' decisions differently between Firm A and Firm B?" We code the response as 1 if a bureaucrat responds that he or she intervenes in Firm A more than Firm B, 0 if the bureaucrat replies that there is no difference in the level of intervention between the two firms, and -1 if the bureaucrat responds that he or she intervenes in Firm B more than Firm A. We reproduce this survey in Appendix Table A.4.

We sent 20 questionnaires to bureaucrats of various local state management offices in Tianjin City and Shangdong Province, with assistance from the Corporate Governance Center of Nankai University. We received 15 valid responses. As reported in Table 11, among the valid responses, the average intervention scores are mostly significantly positive for both long- and short-term decisions, indicating more severe government intervention in firms directly linked to the government than in firms linked with pyramids. Particularly as indicated by the median value of 1 for the intervention score, more than half of the respondents think that intervention in long-term decision-making is more severe in firms directly under government control. The median value for the intervention score of short-term decision making is zero, indicating neither response dominates. However, the signed rank sum test shows a significant tendency toward more severe intervention in firms under direct government control.

In addition to the survey of bureaucrats, we surveyed senior management of SOEs with various numbers of pyramidal layers. ${ }^{11}$ The resulting

11. The description of the survey result is available at http://ihome.cuhk.edu.hk/ $\sim$ b109671. 


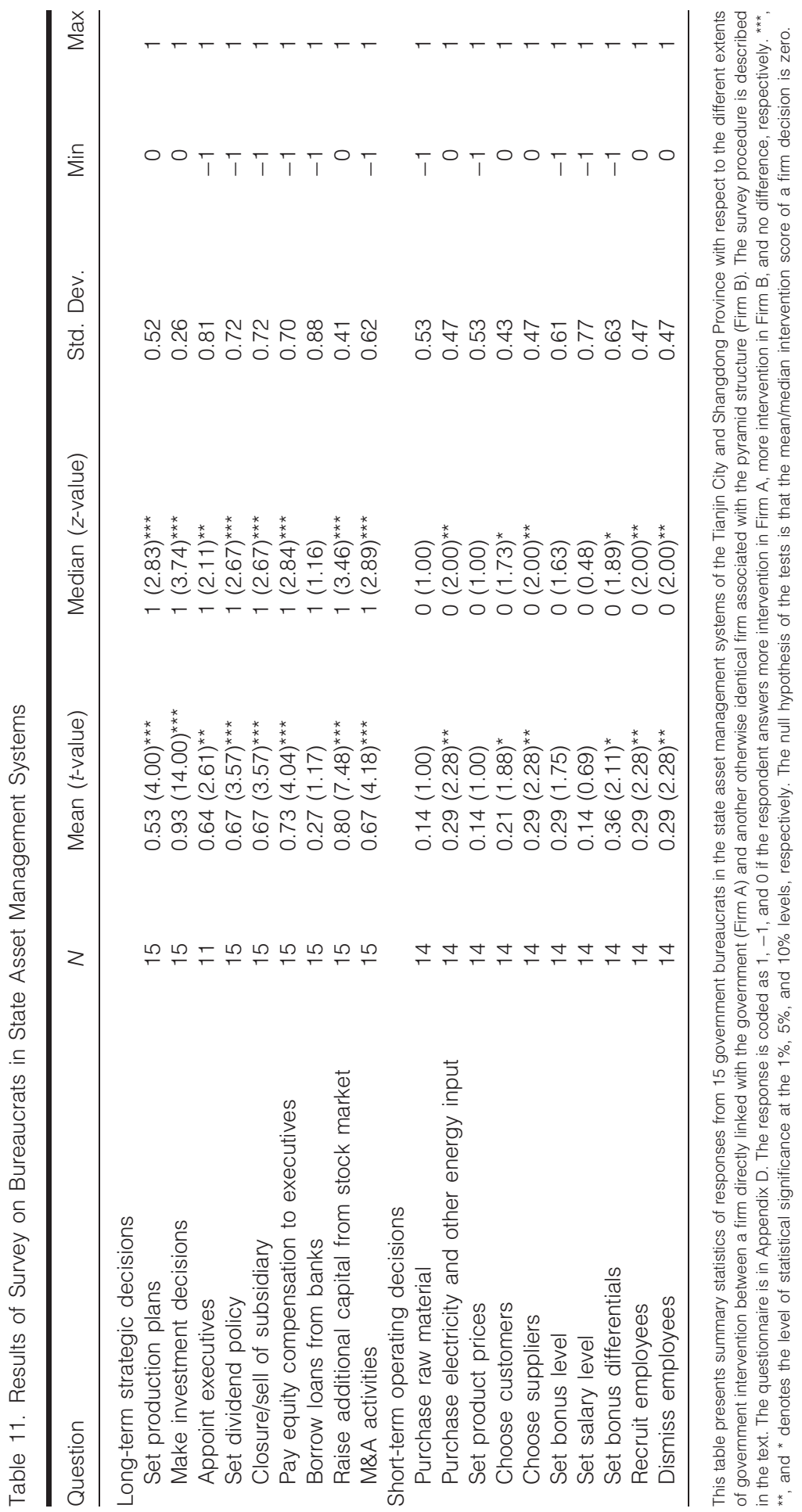


responses also provide evidence supporting our conclusion that managements of firms with more layers have more decision rights.

Overall, the results of surveys presented to state asset management bureaucrats and SOE managers both shows that more firm decision rights are delegated to managers of firms associated with pyramidal organizations than to managers of firms directly linked to government.

\section{Conclusion}

The literature shows that pyramidal organizational structures are associated with agency problems (La Porta et al. 1999), financial constraints (Almeida and Wolfenzon 2006), and taxation (Morck 2005). Yet these insights are specific to privately owned pyramids. In this article, we present early work on the role of state-owned pyramids. In particular, using Chinese data, we provide an explanation for state-owned corporate pyramids: separating firms from political interference.

In contrast to research that points to negative aspects of pyramid structures, we report evidence indicating a positive role. Importantly, our result is not likely to be unique to China or even to state-owned organizations. For instance, the political costs arising from government intervention are a concern not only for SOEs but also for private firms in heavily regulated industries. As one example, in the United States, privately controlled public utility companies have historically been subject to heavy government regulation in the name of the public interest. In the early 20 th century, emerging electric companies avoided regulation by structuring their firms as holding companies (a corporate entity that has controlling interest in another operating company). Throughout the 1920s, public utility holding companies and their subsidiaries bought smaller utilities, and thus public utility organizational pyramids emerged. An important advantage of the public utility pyramids was that operating companies at lower levels were subject to state regulation while holding companies at the top level were not. This allowed holding companies to issue new stock and bonds without state oversight. However, in the aftermath of the stock market crash of 1929, the Public Utility Holding Company Act dismantled organizational pyramids in public utilities in the United States (Morck and Yeung 2005). ${ }^{12}$ This example points to the possibility that concerns about political costs can also affect corporate pyramid structure under private ownership.

12. The Public Utility Holding Company Act outlawed interstate utility holding companies and made it illegal for a holding company to be more than twice removed from its operating subsidiary. The legislation had a swift and dramatic effect on public utility pyramids. Between 1938 and 1958, the number of holding companies fell from 216 to 18. This forced divestiture continued until deregulation in the 1980s and 1990s. See Lai (2001) and Warkentin (1998). 


\section{Appendix A \\ A.1. State Asset Reform in Shanghai and the Creation of Shanghai Construction Group}

Starting in 1993, the Shanghai government took the lead in implementing reform of its state asset management system, with an objective of separating government administration from state asset management. The governments' roles in state assets are regulated following the ThreeSeparation (二分开) Principle: (1) separation between government and enterprises-government will authorize state asset supervisory agencies (bureaus of state assets) to perform the role as capital providers and shareholders but not to involve management of enterprises; (2) separation of government and capital — state asset supervisory agencies will not take up any other public administration role, and other government agencies will not take up any state asset management role; and (3) separation of ownership and management - state asset supervisory agencies will not be directly involved in the operation or management of enterprises (Project Team 2002).

A consequence of the reform is the emergence of pyramidal structure in the state asset management system. In this structure, Shanghai Bureau of State Asset Management sits at the apex of the pyramid as the ultimate owner. But it does not directly manage or operate state assets. One level down the pyramid is a state asset management company. Under the original state asset management system prior to reform, state assets were managed by industrial bureaus. For example, Shanghai Bureau of Construction managed state assets in the construction industry. Following reform, the industrial bureaus were restructured into state asset management companies. The state asset management companies, despite their state ownership background, were economic entities separate from the public administration system. Neither did they directly manage nor operate state assets. Instead, the state asset management companies created new subsidiaries, injected state assets into the subsidiaries, and delegated subsidiary managers to manage the assets.

In addition to the change in organizational structure, the personnel policy in SOEs has changed significantly in the following ways: (1) government confines its direct appointment of and control over personnel only within the Bureau of State Asset Management and state asset management companies, the top two layers of the pyramid, whereas the personnel decisions of the bottom layer of subsidiaries are delegated to the state asset management companies; (2) the executives of state asset management companies and other affiliated firms do not have government titles or ranks; (3) the CEO and CFO of a publicly listed subsidiary are nominated by the chairman of the board and appointed by the board of directors; and (4) market-based incentive schemes, such as annual compensation and equity-based compensation, are introduced to publicly listed subsidiaries. The organizational transformation associated with 
state asset reform can be illustrated by the formation of Shanghai Construction Group as reported in Zhang and Cai (1996).

Shanghai Bureau of Construction, a government agency founded in 1953, was in charge of the operations in the construction industry in the Shanghai region. In the planned economy era, all construction projects were planned, financed, and executed by the Bureau. In 1994, the Bureau was restructured into Shanghai Construction Group under the guidance of Shanghai Bureau of State Assets, employing almost 70,000 employees and registering more than 1 billion Ren Min Bi of capital. The assets originally managed by the Bureau were transferred to newly formed subsidiaries of the Group. Managers of the subsidiaries reported to their corresponding boards of directors, in contrast to prior practices, when they had to report to government officials. The original public administration function of the Bureau of Construction was transferred to a separate government agency, the Committee of Construction (市趡设委点会), which was not involved in any operation of state assets.

Consistent with the Shanghai Government's state asset reform principles, the restructuring and the establishment of Shanghai Construction Group were intended to draw a bright line between the government and the construction business, and to empower managers. The organizational restructuring was associated with subsequent expansion in market share, substantial increase in research and development expenditure, and new technology development. The Group also expanded its overseas operations through opening branch offices and establishing subsidiaries.

Table A.2. Variable Definitions and Data Sources

\begin{tabular}{|c|c|c|}
\hline Variable & Description & Sources \\
\hline Unemployment & $\begin{array}{l}\text { The unemployment rate officially reported for each } \\
\text { province, autonomous region, and municipality. } \\
\text { The data are available annually. }\end{array}$ & $\begin{array}{l}\text { China Information } \\
\text { Bank }\end{array}$ \\
\hline Fiscal Surplus & $\begin{array}{l}\text { A dummy variable that equals } 1 \text { if the fiscal } \\
\text { revenue minus government expenditure scaled by } \\
\text { GDP of a region is above the top quartile level of } \\
\text { all regions in China, and zero otherwise. The data } \\
\text { are available annually. }\end{array}$ & $\begin{array}{l}\text { China Information } \\
\text { Network Data Co., } \\
\text { Ltd. }\end{array}$ \\
\hline R\&D (\%) & $\begin{array}{l}\text { The expenditure on fundamental research, applied } \\
\text { research, experimental development, and capital } \\
\text { construction for scientific research in a region } \\
\text { scaled by the GDP of the region. The data are as } \\
\text { of } 2000 .\end{array}$ & $\begin{array}{l}\text { National Bureau of } \\
\text { Statistics }\end{array}$ \\
\hline $\begin{array}{l}\text { Aggregate } \\
\text { Incentive }\end{array}$ & $\begin{array}{l}\text { The factor score for the first component extracted } \\
\text { from the principal component analysis of } \\
\text { Unemployment, Fiscal Surplus, and R\&D. This is } \\
\text { the only component that satisfies the Kaiser criter- } \\
\text { ion, capturing } 54 \% \text { of the total variance. }\end{array}$ & Authors' estimation \\
\hline Marketization & $\begin{array}{l}\text { This is a comprehensive index that captures the fol- } \\
\text { lowing aspects of regional market development: }\end{array}$ & $\begin{array}{l}\text { Fan and Wang } \\
(2001)^{\mathrm{a}}\end{array}$ \\
\hline
\end{tabular}


Table A.2. Continued

\begin{tabular}{|c|c|c|}
\hline Variable & Description & Sources \\
\hline & $\begin{array}{l}\text { (1) relationship between government and market, } \\
\text { including the role of market in allocating re- } \\
\text { sources and firm's policy burden in addition to } \\
\text { taxes; (2) development of nonstate business in } \\
\text { terms of the ratio of industrial output by private } \\
\text { sector to total industrial output; (3) development } \\
\text { of product markets in terms of the degree of } \\
\text { regional trade barriers; (4) development of factor } \\
\text { markets captured by foreign direct investment } \\
\text { and labor mobility; and (5) development of market } \\
\text { intermediaries and legal environment. These vari- } \\
\text { ous components of the index are constructed } \\
\text { based on the research, such as Beck and Levine } \\
\text { (2002), Brandt and Li (2003), Javorcik (2004), } \\
\text { Johnson et al. (2002), La Porta et al. (1999, } \\
2002 \text { ), and Wurgler (2000). We use the average } \\
\text { of the } 1999 \text { and } 2000 \text { indexes in our analyses. }\end{array}$ & \\
\hline Legal Environment & $\begin{array}{l}\text { This index measures the development of market } \\
\text { intermediaries, protection of property rights, copy- } \\
\text { rights, and consumers. We use the average of } \\
\text { the } 1999 \text { and } 2000 \text { indexes in our analyses. }\end{array}$ & Fan and Wang (2001) \\
\hline Property rights & $\begin{array}{l}\text { This index is calculated based on the total } \\
\text { economic value of legal cases settled, } \\
\text { standardized by GDP of the region. This measure } \\
\text { is based on the design in Johnson et al. (2002) } \\
\text { to capture the court system's ability to enforce } \\
\text { contracts. We use the average of the } 1999 \text { and } \\
2000 \text { indexes in our analyses. }\end{array}$ & Fan and Wang (2001) \\
\hline Deregulation & $\begin{array}{l}\text { The amount of preferential treatments granted to a } \\
\text { region by the central government to set up spe- } \\
\text { cial economic zones during the period 1978- } \\
1998 \text {. }\end{array}$ & $\begin{array}{l}\text { Demruger et al. } \\
\text { (2002) }\end{array}$ \\
\hline FDI & $\begin{array}{l}\text { The annual flow of foreign direct investment scaled } \\
\text { by GDP of the region for the year. }\end{array}$ & $\begin{array}{l}\text { China Information } \\
\text { Network Data Co., } \\
\text { Ltd. }\end{array}$ \\
\hline Openness & $\begin{array}{l}\text { The total foreign imports and exports scaled by } \\
\text { GDP of the region for the year. }\end{array}$ & $\begin{array}{l}\text { China Information } \\
\text { Network Data Co., } \\
\text { Ltd. }\end{array}$ \\
\hline $\begin{array}{l}\text { Aggregate } \\
\text { Institutions }\end{array}$ & $\begin{array}{l}\text { The factor score for the first component extracted } \\
\text { from the principal component analysis of the four } \\
\text { institutional indexes: Marketization, Legal } \\
\text { Environment, Property Rights, and Deregulation. } \\
\text { This is the only component that satisfies the } \\
\text { Kaiser criterion, capturing } 76 \% \text { of the total } \\
\text { variance. }\end{array}$ & Authors' estimation \\
\hline
\end{tabular}

${ }^{a}$ Fan and Wang (2001) conduct the NERI Index project, which was sponsored by the NERI and the China Reform Foundation. The NERI indices capture the progress of institutional transition in China's 30 provinces (excluding Tibet, due to lack of data). Appraisals of regional institutions are made along several dimensions, namely, the relationship between the government and the market, the development of the non-state sector, the development of the factor markets, the development of the product markets, and the development of market intermediaries and the legal environment. The data in the NERI Index project mainly come from the statistical yearbooks of the National Statistics Bureau, which contain statistical information about prices and administration of industry and commerce, the courts, consumer associations, as well as the government's statistical information from bank surveys and the entrepreneur survey system, and survey information about rural households from the National Statistics Bureau. 


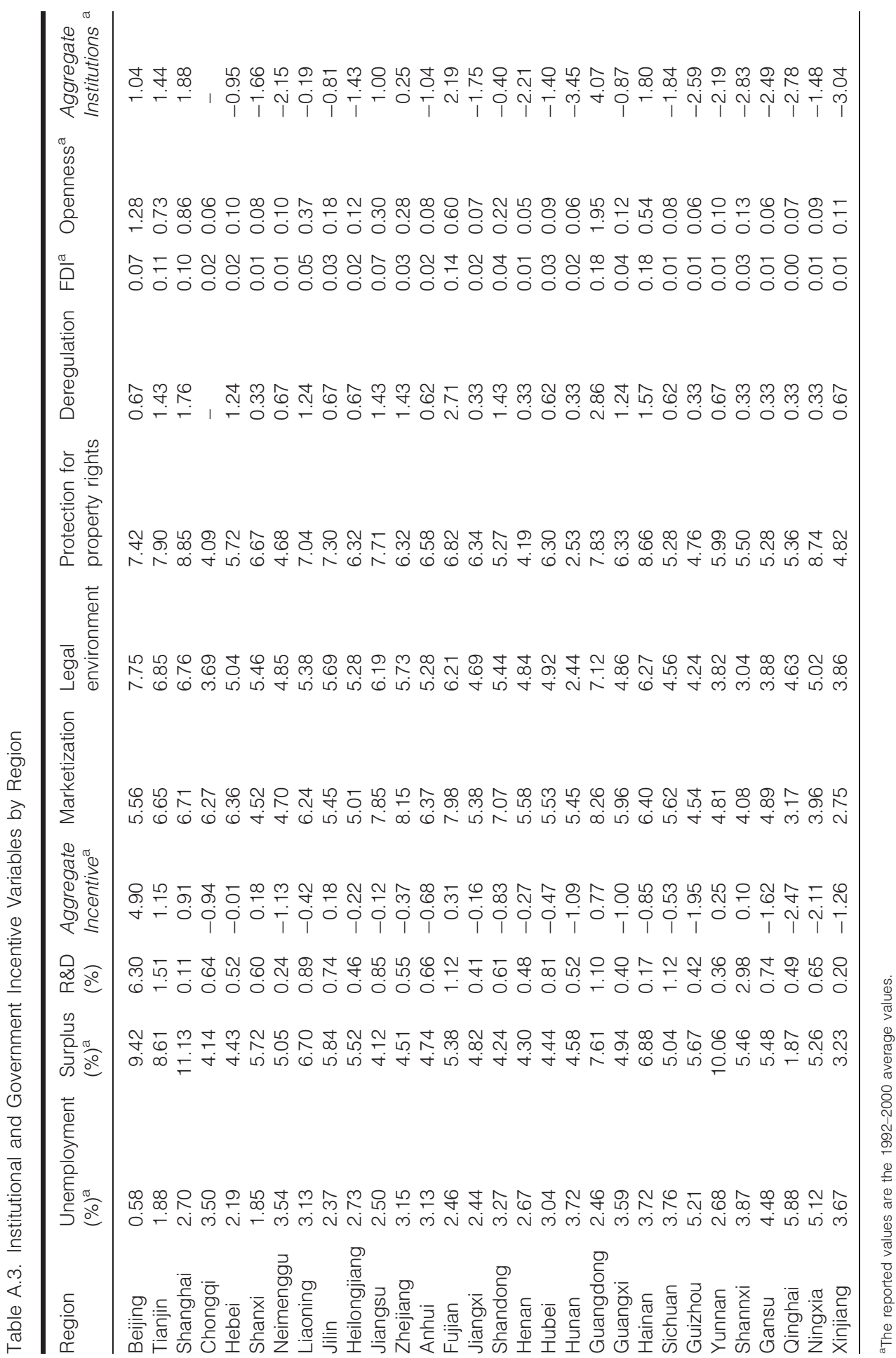


Table A.4. Questionnaire for Bureaucrats of State Asset Management Systems As a majority shareholder, do you intervene in the following decisions differently in Firms A and $B$ [Note: Firms A and B are different in ownership structure but the same in all other aspects.]?
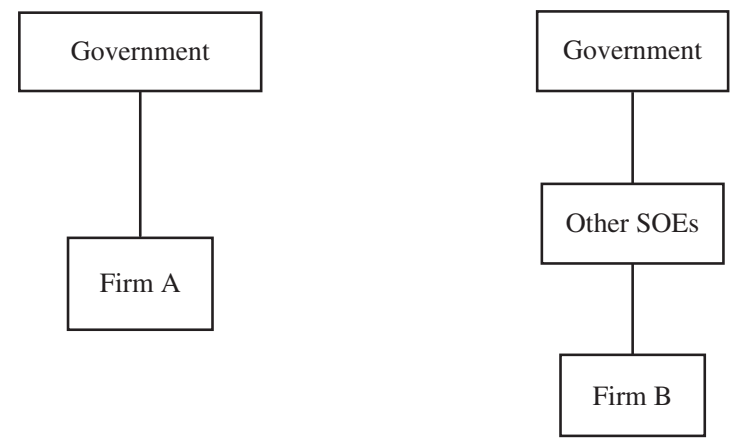

Long-term strategic decisions

Set production plans

Make investment decisions

Appoint executives

More on $A$

\section{$\square$ More on B}

No difference

More on A

More on A

Set dividend policy

More on A

More on A

Closure/sell of subsidiary

More on $A$

More on A

Borrow loans from banks

More on A

Raise additional capital from stock market

More on $A$

More on B

No difference

$\square$ More on B

No difference

$\square$ More on B

No difference

$\square$ More on B

No difference

$\square$ More on B $\square$ No difference

M\&A activities

$\square$ More on B $\square$ No difference

$\square$ More on B $\square$ No difference

Short-term operating decisions

Purchase raw material

More on $\mathrm{A}$

$\square$ More on B

No difference

Purchase electricity and other energy input

Set product prices

More on A

More on $A$

More on $A$

More on $A$

More on A

More on A

More on A

More on A

More on $A$

$\square$ More on B

No difference

$\square$ More on B $\square$ No difference

Choose customers

$\square$ More on B

$\square$ More on B

No difference

Choose suppliers

$\square$ More on B

No difference

Set bonus level

Set salary differentials

$\square$ More on B

No difference

Set bonus differentials

$\square$ More on B

No difference

Recruit employees

$\square$ More on B

No difference

Dismiss employees

$\square$ More on B

No difference

No difference

No difference

\section{References}

Acemoglu, Daron, Simon Johnson, and James Robinson. 2001. "The Colonial Origins of Comparative Development: An Empirical Investigation," 91 The American Economic Review 1369-401.

Aghion, Philippe, and Jean Tirole. 1997. "Formal and Real Authority in Organizations," 105 The Journal of Political Economy 1-29.

Almeida, Heitor V., and Daniel Wolfenzon. 2006. "A Theory of Pyramidal Ownership and Family Business Group,” 61 The Journal of Finance 2637-80.

Almeida, Heitor V., Sang Y. Park, Marti G. Subrahmanyam, and Daniel Wolfenzon. 2011. "The Structure and Formation of Business Groups: Evidence from Korean Chaebols," 99 Journal of Financial Economics 447-75. 
Baker, George P. 1992. "Beatrice: A Study in the Creation and Destruction of Value," 47 The Journal of Finance 1081-119.

Baker, George, Robert Gibbons, and Kevin J. Murphy. 1999. "Informal Authority in Organizations," 15 The Journal of Law, Economics, \& Organization 56-73.

Bebchuk, Lucian. 1999. "A Rent-Seeking Theory of Corporate Ownership and Control," NBER Working Paper Number 7203.

Bebchuk, Lucian, Reinier Kraakman, and George Triantis. 2000. "Stock Pyramids, Cross-Ownership, and Dual Class Equity: The Creation and Agency Costs of Separating Control from Cash Flow Rights," Randall Morck, ed., Concentrated Corporate Ownership. National Bureau of Economic Research Conference Volume. Chicago, IL: University of Chicago Press.

Beck, T., and R. Levine. 2002. "Industry Growth and Capital Allocation: Does Having a Market- or Bank-based System Matter?," 64 Journal of Financial Economics $147-80$.

Bertrand, Marianne, Paras Mehta, and Sendhil Mullainathan. 2002. "Ferreting out Tunneling: An Application to Indian Business Groups," 117 The Quarterly Journal of Economics 121-48.

Brandt, Loren, and Hong B. Li. 2003. "Bank Discrimination in Transition Economies: Ideology, Information, or Incentives?," 31 Journal of Comparative Economics 387-413.

Brandt, Loren, and Xiao Z. Zhu. 2000. "Redistribution in a Decentralized Economy: Growth and Inflation in China," 108 The Journal of Political Economy 422-39.

Burkart, Mike, Denis Gromb, and Fausto Panunzi. 1997. "Large Shareholders, Monitoring, and the Value of the Firm," 112 The Quarterly Journal of Economics 693-728.

Chernykh, Lucy. 2008. "Ultimate Ownership and Control in Russia," 88 Journal of Financial Economics 169-92.

Claessens, Stijn, Simeon Djankov, Joseph P.H. Fan, and Larry H.P. Lang. 2002. "Disentangling the Incentive and Entrenchment Effects of Large Shareholdings," 57 The Journal of Finance 2741-71.

Claessens, Stijn, Simeon Djankov, and Larry H.P. Lang. 2000. "The Separation of Ownership and Control in East Asian Corporations," 58 Journal of Financial Economics 81-112.

Cremer, Jacques. 1995. "Arm's Length Relationships," 110 The Quarterly Journal of Economics 275-95.

de Jong, Douglas V., Abe De Jong, Gerard Mertens, and Ulrich Hege. 2010. "Leverage in Pyramids: When Debt Leads to Higher Dividends," Working Paper, HEC Paris.

Demruger, Sylvie, Jeffrey D. Sachs, Wing Thye Woo, Shuming Bao, Gene Chang, and Andrew Mellinger. 2002. "Geography, Economic Policy and Regional Development in China," 1 Asian Economics Papers 146-97.

Fairbank, John K., and Merle Goldman. 1992. China: A New History. London: The Belknap Press of Harvard University Press.

Fan, Gang, and Xiao L. Wang. 2001. NERI Index of Marketization of China's Provinces. Beijing: Economics Science Press (In Chinese).

Fan, Joseph P.H., T.J. Wong, and Tianyu Zhang. 2007. "Politically Connected CEOs, Corporate Governance and Post-IPO Performance of China's Partially Privatized Firms," 84 Journal of Financial Economics 330-57.

Garnaut, Ross, Ligang Song, Stoyan Tenev, and Yang Yao. 2005. China's Ownership Transformation: Process, Outcomes, Prospects. Washington, DC: International Finance Corporation and International Bank for Reconstruction and Development/World Bank.

Grove, Theodore, Yongmiao Hong, John McMillan, and Barry Naughton. 1994. "Autonomy and Incentives in Chinese State Enterprises," 101 The Quarterly Journal of Economics 183-209.

Javorcik, Beata S. 2004. "Does Foreign Direct Investment Increase the Productivity of Domestic Firms? In Search of Spillovers Through Backward Linkages," 94 American Economic Review 605-27. 
Jensen, Michael C., and William H. Meckling. 1992. "Specific and General Knowledge, and Organizational Structure," in Hans Wijkander Lars Werin, ed., Contract Economics. Oxford: The Blackwell Press.

Jones, Geoffrey. 2000. Merchants to Multinationals. Oxford: Oxford University Press.

Johnson, Simon, John McMillan, and Christopher Woodruff. 2002. "Property Rights and Finance," 92 American Economic Review 1335-56.

Keister, Lisa. A. 2000. Chinese Business Groups: The Structure and Impact of Inter-firm Relations during Economic Development. New York, NY: Oxford University Press.

Khanna, Tarun, and Catherine Thomas. 2009. "Synchronicity and Firm Interlocks in an Emerging Market," 92 Journal of Financial Economics 182-204.

Khanna, Tarun, and Jan W. Rivkin. 2001. "Estimating the Performance Effects of Business Groups in Emerging Markets," 22 Strategic Management Journal 45-74.

Khanna, Tarun, and Yafeh Yishay. 2007. "Business Groups in Emerging Markets, Paragons or Parasites?," 45 Journal of Economic Literature 331-72.

La Porta, Rafael, Florencio Lopez-de-Silanes, and Andrei Shleifer. 1999. "Corporate Ownership around the World," 54 The Journal of Finance 471-518.

La Porta, Rafael, Florencio Lopez-de-Silanes, Andrei Shleifer, and Robert Vishny. 2002. "Investor Protection and Corporate Valuation," 57 Journal of Finance 1147-70.

Lai, Loi Lei. 2001. Power System Restructuring and Deregulation. New York, NY: Wiley.

Lemmon, Michael L., and Karl V. Lins. 2003. "Ownership Structure, Corporate Governance, and Firm Value: Evidence from the East Asian Financial Crisis," 58 Journal of Finance 1445-68.

Lin, J. Y., and Z. Li. 2008. "Policy Burden, Privatization and Soft Budget Constraint," 36 Journal of Comparative Economics 90-102.

Maskin, Eric, Ying Y. Qian, and Cheng G. Xu. 2000. "Incentives, Information, and Organizational Form," 67 The Review of Economics Studies 359-78.

Masulis, Ronald W., Peter K. Pham, and Jason Zein. 2011. "Family Business Groups around the World: Costs and Benefits of Pyramids," Working Paper, University of New South Wales.

Morck, Randall. 2005. "How to Eliminate Pyramidal Business Groups: The Double Taxation of Inter-corporate Dividends and Other Incisive Use of Tax Policy," in P. James, ed., National Bureau of Economic Research Tax Policy Annual. Chicago, IL: University of Chicago Press.

Morck, Randall, and Bernard Yeung. 2005. "Dividend Taxation and Corporate Governance," 19 Journal of Economic Perspectives 163-80.

Morck, Randall, David A. Stangeland, and Bernard Yeung. 2000. "Inherited Wealth, Corporate Control, and Economic Growth: The Canadian Disease," Randall Morck, ed., Concentrated Corporate Ownership. National Bureau of Economic Research Conference Volume. Chicago, IL: University of Chicago Press.

Morck, Randall, Daniel Wolfenzon, and Bernard Yeung. 2004. "Corporate Governance, Economic Entrenchment and Growth," 43 Journal of Economic Literature 657-722.

Organization for Economic Co-operation and Development. 2005. Corporate Governance of State-owned Enterprises: A Survey of OECD Countries. The OECD Publishing.

Prat, Andrea. 2005. "The Wrong Kind of Transparency," 95 The American Economic Review 862-77.

Project Team. 2002. Exploration and Innovation of Modern Corporate System in Shanghai. Shanghai: Shanghai Education Press (in Chinese).

Qian, Ying Y. 1995. "Reforming Corporate Governance and Finance in China," in M. Aoki, and H. Kim, eds., Corporate Governance in Transition Economies: Insider Control and the Role of Banks. Washington, DC: World Bank.

1996. "Enterprise Reform in China: Agency Problems and Political Control," 4 Economics of Transition 427-47.

Qian, Ying Y., and Jing L. Wu. 2003. "China's Transition to a Market Economy: How Far Across the River," in C. Nicholas, Dennis Tao Yang Hope, and Mu Yang Li, eds., How 
Far Across the River: Chinese Policy Reform at the Millennium. Stanford, CA: Stanford University Press.

Rajan, Raghuram G., and Julie Wulf. 2006. "The Flattening Firm: Evidence on the Changing Nature of Firm Hierarchies from Panel Data," 88 The Review of Economics and Statistics 759-73.

Shirley, Mary, and Patrick Walsh. 2001. "Public versus Private Ownership: The Current State of the Debate," Working Paper 2420, World Bank.

Shleifer, Andrei, and Robert W. Vishny. 1994. "Politicians and Firms," 109 The Quarterly Journal of Economics 995-1025.

- 1998. The Grabbing Hand: Government Pathologies and Their Cures. Cambridge, MA: Harvard University Press.

Stein, Jeremy C. 2002. "Information Production and Capital Allocation: Decentralized versus Hierarchical Firms," 57 The Journal of Finance 1891-921.

Tenev, Stoyan, Chunlin Zhang, and Loup Brefort. 2002. Corporate Governance and Enterprise Reform in China. Washington, DC: World Bank and International Finance Corporation.

Voska, Eva. 1993. Restructuring of Large State Owned Enterprises in Hungary 1988-1993. Working Paper, United Nations Economic Commission for Europe.

Warkentin, Denise. 1998. Electric Power Industry in Nontechnical Language. Tulsa, Oklahoma: Penn Well Publishers.

Williamson, Oliver E. 1985. The Economic Institutions of Capitalism. New York, NY: The Free Press.

Wolfenzon, Daniel. 1999. “A Theory of Pyramidal Ownership,” Working Paper. New York University.

$\mathrm{Wu}$, Jing L. 2005. Understanding and Interpreting Chinese Economic Reform. Mason, OH: South-Western.

Wurgler, Jeffrey. 2000. "Financial Markets and the Allocation of Capital," 58 Journal of Financial Economics 187-214.

Zhang, X.H., and W. Z. Cai. 1996. Top 100 Enterprises in Reform Era. Shanghai: Lixin Accounting Press (in Chinese). 